Review

\title{
An Overview of Parameter and Cost for Battery Electric Vehicles
}

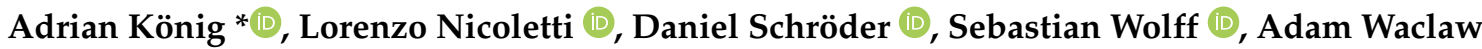 \\ and Markus Lienkamp
}

check for

updates

Citation: König, A.; Nicoletti, L.; Schröder, D.; Wolff, S.; Waclaw, A.; Lienkamp, M. An Overview of Parameter and Cost for Battery Electric Vehicles. World Electr. Veh. J. 2021, 12, 21. https://doi.org/ 10.3390/wevj12010021

Received: 13 January 2021

Accepted: 30 January 2021

Published: 3 February 2021

Publisher's Note: MDPI stays neutral with regard to jurisdictional claims in published maps and institutional affiliations.

Copyright: (c) 2021 by the authors. Licensee MDPI, Basel, Switzerland. This article is an open access article distributed under the terms and conditions of the Creative Commons Attribution (CC BY) license (https:/ / creativecommons.org/licenses/by/ $4.0 /)$.
Institute of Automotive Technology, Technical University of Munich, Boltzmannstraße 15, 85748 Garching, Germany; nicoletti@ftm.mw.tum.de (L.N.); schroeder@ftm.mw.tum.de (D.S.); wolff@ftm.mw.tum.de (S.W.); waclaw@ftm.mw.tum.de (A.W.); lienkamp@ftm.mw.tum.de (M.L.)

* Correspondence: adrian.koenig@ftm.mw.tum.de

\begin{abstract}
The launch of both battery electric vehicles (BEVs) and autonomous vehicles (AVs) on the global market has triggered ongoing radical changes in the automotive sector. On the one hand, the new characteristics of the BEV powertrain compared to the combustion type have resulted in new central parameters, such as vehicle range, which then become an important selling point. On the other hand, electric components are as yet not optimized and the sensors needed for autonomous driving are still expensive, which introduces changes to the vehicle cost structure. This transformation is not limited to the vehicle itself but also extends to its mobility and the necessary infrastructure. The former is shaped by new user behaviors and scenarios. The latter is impacted by the BEV powertrain, which requires a charging and energy supply infrastructure. To enable manufacturers and researchers to develop and optimize BEVs and AVs, it is necessary to first identify the relevant parameters and costs. To this end, we have conducted an extensive literature review. The result is a complete overview of the relevant parameters and costs, divided into the categories of vehicle, infrastructure, mobility, and energy.
\end{abstract}

Keywords: battery electric vehicles; design parameters; cost assessment

\section{Introduction and Background}

The megatrends of electrification and automation are posing new challenges for automotive manufacturers [1], giving rise to new requirements for future vehicles and leading the way to new, as yet unexplored, mobility systems. Powertrain electrification, for example, promises a cleaner future, while autonomous driving will improve safety, availability, and efficiency [2]. However, these trends also set new boundary conditions during vehicle development and create different cost structures. In the case of BEVs, the traction battery increases both the vehicle's weight [3] and purchase price compared to internal combustion engine vehicles (ICEVs). Moreover, sensors and computers in autonomous vehicles (AVs) impact auxiliary power consumption and acquisition costs. Detailed knowledge of the new technologies and their costs is a key requirement of automotive manufacturers' ability to plan future vehicle concepts and ensure their success in the market.

To profit from new technologies, concept engineers need to identify optimal technical solutions for individual components and vehicle packages, which requires detailed knowledge of the relevant technical parameters. However, the best technical solution is generally also the most expensive one. Thus, both technical suitability and cost are relevant optimization objectives that enable an assessment of new vehicle concept's feasibility.

The aim of this paper is to provide an overview of the cost structure of BEVs and AVs and to identify the relevant technical parameters. Since BEVs and AVs require new technologies and components, we first discuss the relevant parameters and assess their costs (Section 2). Subsequently, since automation and electrification trigger changes in mobility concepts, we assess the costs associated with various mobility solutions and identify parameters that describe new mobility behaviors (Section 3). Changes in mobility 
in turn require a charging infrastructure, and this is described in Section 4. Finally, we present an overview of energy costs incurred in the operation of the charging infrastructure (Section 5).

This paper is based on two former publications by our Institute of Automotive Technology from 2014 and 2017 [4,5], which provided costs for vehicles, energy, and $\mathrm{CO}_{2}$. We provide updated values in the following and add important parameters and costs for mobility and infrastructure.

\section{Cost Assessment Assumptions}

We obtained our data from technical experts, scientific papers, and internet sources. Most sources do not indicate whether the stated prices are for customers or manufacturers, while the costs given refer to different years and currencies. We therefore make the following assumptions, following the approach taken in [5]:

- The exchange rate used to calculate the price in Euro is fixed and based on [6]. We apply the average exchange rate for the year 2019 , which is $\$ 1.13$ to $€ 1$.

- Inflation is taken into account in accordance with [7]. The year to which the price refers is taken from the publishing date of the source unless it is explicitly given.

- Component costs taken from the literature or other sources are assumed to apply to manufacturers.

\section{Vehicle Parameters}

The cost structure of a BEV is different from that of an ICEV. Battery costs alone can account for up to one-third of total vehicle costs, as can be seen from Figure 1, which compares the costs of a compact ICEV with those of a comparable BEV with a $50 \mathrm{kWh}$ battery. In 2020, an ICEV is still significantly cheaper than a BEV, while, by 2030, falling battery prices will reduce the price difference to only $9 \%[8,9]$.

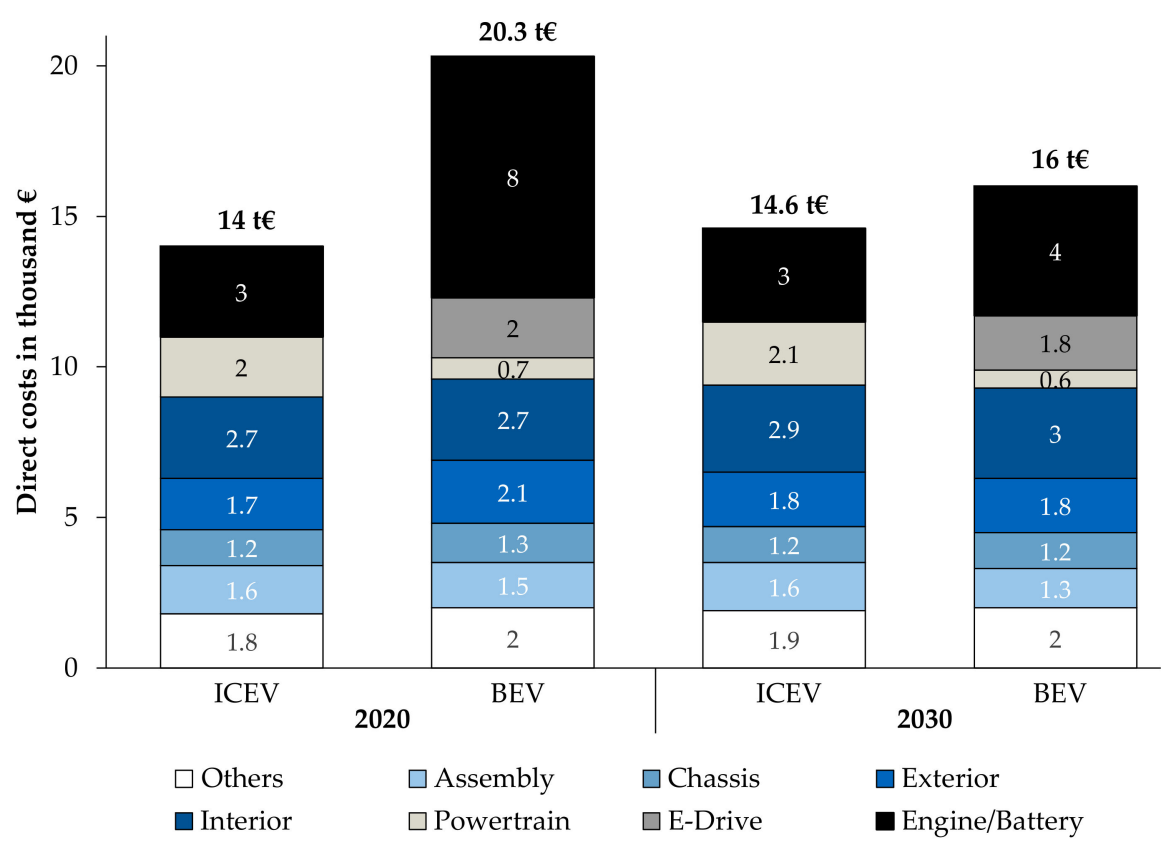

Figure 1. Cost structure of current and future BEVs compared to ICEVs $[8,9]$.

In the following, we will focus on the BEV powertrain (Section 2.1), as it is the module whose components have the highest influence on the overall vehicle cost structure. We then present glider costs, including interior and exterior components (Section 2.2). Since the automation of the driving function represents a promising development in the automotive industry, along with electrification, we also consider other necessary components. We 
therefore estimate the costs of those components needed for driver assistance systems and autonomous driving (Section 2.3).

\subsection{Powertrain Components}

In this section, we focus on the main components of the BEV powertrain, identify their relevant parameters, and assess their typical values. We look in particular at the following components:

- Traction battery

- Electric machine

- Gearbox

- Power electronics

Particular attention is given to the traction battery, as it represents the central component of the BEV powertrain.

\subsubsection{Traction Battery}

The currently established technology for BEVs is the lithium-ion battery [10]. A lithium-ion battery consists of interconnected cells, with cell dimensions (length, width, and height) and shape (pouch, prismatic, and cylindrical) varying depending on the manufacturer. For example, Tesla uses cylindrical cells, BMW has prismatic cells, and Nissan employs pouch cells [11].

To describe the traction battery, we focus on its central parameters. According to Matz [12], these are:

- Gravimetric energy density (in $\mathrm{Wh} / \mathrm{kg}$ ) at cell and pack level

- Volumetric energy density (in Wh/L) at cell and pack level

- Battery C-rate

- Number of battery cycles

- $\quad$ Cost in $€ / \mathrm{kWh}$

The energy density of lithium-ion cells has been increasing steadily in recent years on both a gravimetric and a volumetric level.

Figure 2 shows the past and future development of gravimetric energy density between the years 2010 and 2030. It compares the gravimetric cell densities of different BEVs (from the years 2010 to 2020) taken from [11,13-15] with expert projections [12,16-21].

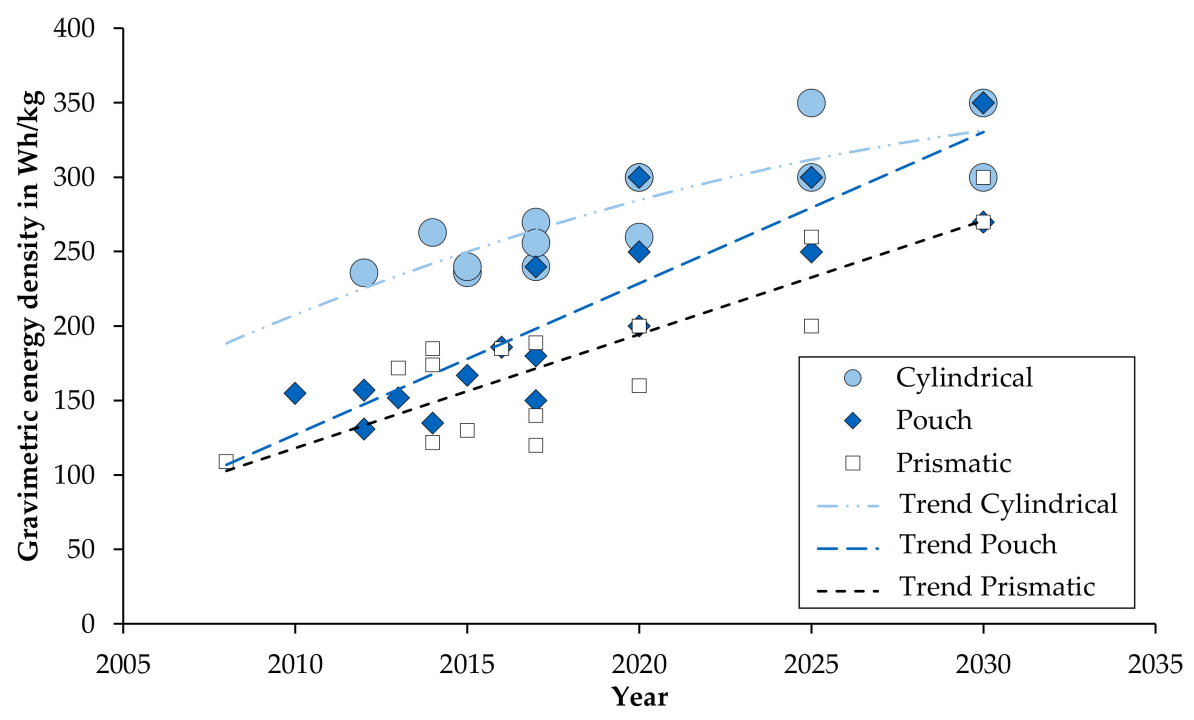

Figure 2. Development of gravimetric energy density at cell level between 2010 and 2030.

Back in 2012, the gravimetric energy density of cylindrical cells was almost $100 \mathrm{Wh} / \mathrm{kg}$ higher than pouch and prismatic cells. Nevertheless, the research presented in [19] and 
the projection shown in [20] suggest that pouch and prismatic cells should be displaying a similar performance by 2030. The trend in Figure 2 suggests that pouch cells will continue to show more promise than prismatic cells in the long term. Nevertheless, the increase in energy density has its limits: Fink [16] puts the practical limit at $370 \mathrm{Wh} / \mathrm{kg}$ while Thielmann [19] and Frieske [22] set it at $350 \mathrm{Wh} / \mathrm{kg}$. Since the limit is expected to be reached by 2030 , new cell chemistry and technology will be needed to make further progress in gravimetric energy density.

Figure 3 shows the trends for volumetric energy density between the years 2010 and 2030. It compares several BEVs (from the years 2010 to 2020) from [11,13-15] with expert projections [18-21]. According to this, pouch cells should attain volumetric energy density values comparable to cylindrical cells by 2030 . All cell types should be able to reach values of around $1000 \mathrm{Wh} / \mathrm{L}$ by 2030 .

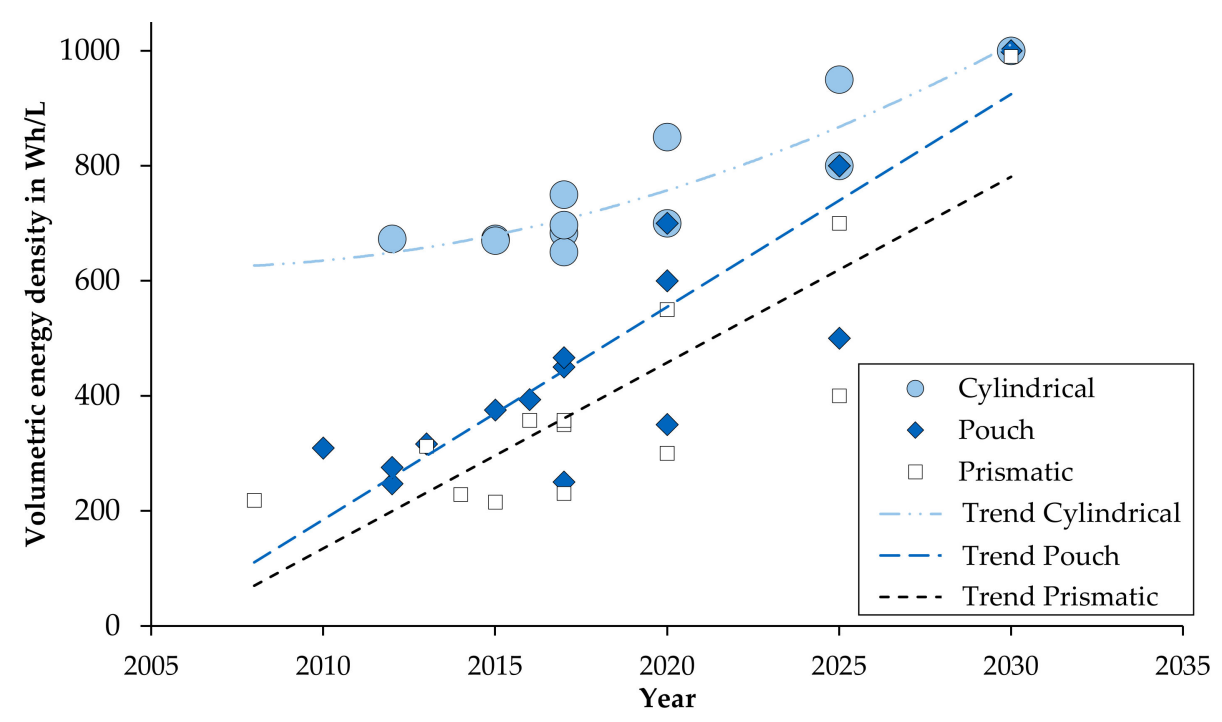

Figure 3. Development of volumetric energy density at the cell level between 2010 and 2030.

The values showed in Figures 2 and 3 are set out in Table 1. The projection for the years 2020, 2025, and 2030 is derived from the average energy density values listed in $[19,20]$.

Table 1. Development of volumetric and gravimetric energy densities at the cell level.

\begin{tabular}{ccccccc}
\hline Year & \multicolumn{2}{c}{ Cylindrical Cell } & \multicolumn{2}{c}{ Prismatic Cell } & \multicolumn{2}{c}{ Pouch Cell } \\
\hline & Gravimetric & Volumetric & Gravimetric & Volumetric & Gravimetric & Volumetric \\
\hline 2020 & $287 \mathrm{Wh} / \mathrm{kg}$ & $775 \mathrm{Wh} / \mathrm{L}$ & $187 \mathrm{Wh} / \mathrm{kg}$ & $425 \mathrm{Wh} / \mathrm{L}$ & $250 \mathrm{Wh} / \mathrm{kg}$ & $550 \mathrm{Wh} / \mathrm{L}$ \\
2025 & $325 \mathrm{Wh} / \mathrm{kg}$ & $875 \mathrm{Wh} / \mathrm{L}$ & $230 \mathrm{Wh} / \mathrm{kg}$ & $550 \mathrm{Wh} / \mathrm{L}$ & $283 \mathrm{Wh} / \mathrm{kg}$ & $700 \mathrm{Wh} / \mathrm{L}$ \\
2030 & $325 \mathrm{Wh} / \mathrm{kg}$ & $1000 \mathrm{Wh} / \mathrm{L}$ & $285 \mathrm{Wh} / \mathrm{kg}$ & $990 \mathrm{Wh} / \mathrm{L}$ & $323 \mathrm{Wh} / \mathrm{kg}$ & $1000 \mathrm{Wh} / \mathrm{L}$ \\
\hline
\end{tabular}

Energy densities at the cell level are not directly scalable to pack level, since the battery also contains other components such as cooling, wires, and module covers [23]. This means that the energy density at the pack level is lower than at the cell level. It is therefore necessary to evaluate the densities at the pack level.

During its recent "Tesla Battery days" [24], Tesla announced a new integration principle to be applied to upcoming models, which it calls the cell-to-pack strategy [25]. The aim of this strategy is to supposedly eliminate the cell modules, thus reducing the mass of the battery by about $10 \%$ [25]. Furthermore, elimination of the module casings should also increase the volumetric energy density at the pack level. However, to date, there is no vehicle with a cell-to-pack strategy, and an assessment of the energy densities with the cell-to-pack strategy is currently not possible. For the moment, it is only possible to assess 
energy densities for existing BEVs. To make this assessment, we therefore distinguish between gravimetric energy density (Figure 4) and volumetric energy density (Figure 5).

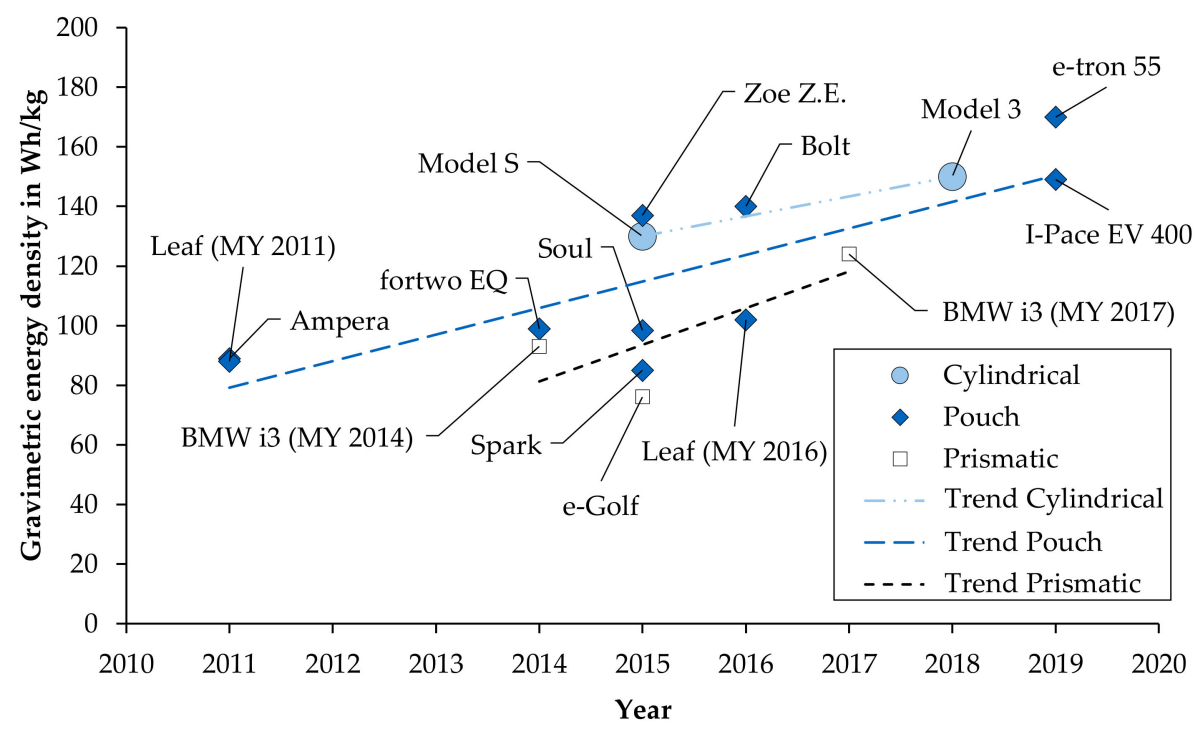

Figure 4. Overview of gravimetric energy density at the pack level for different BEVs.

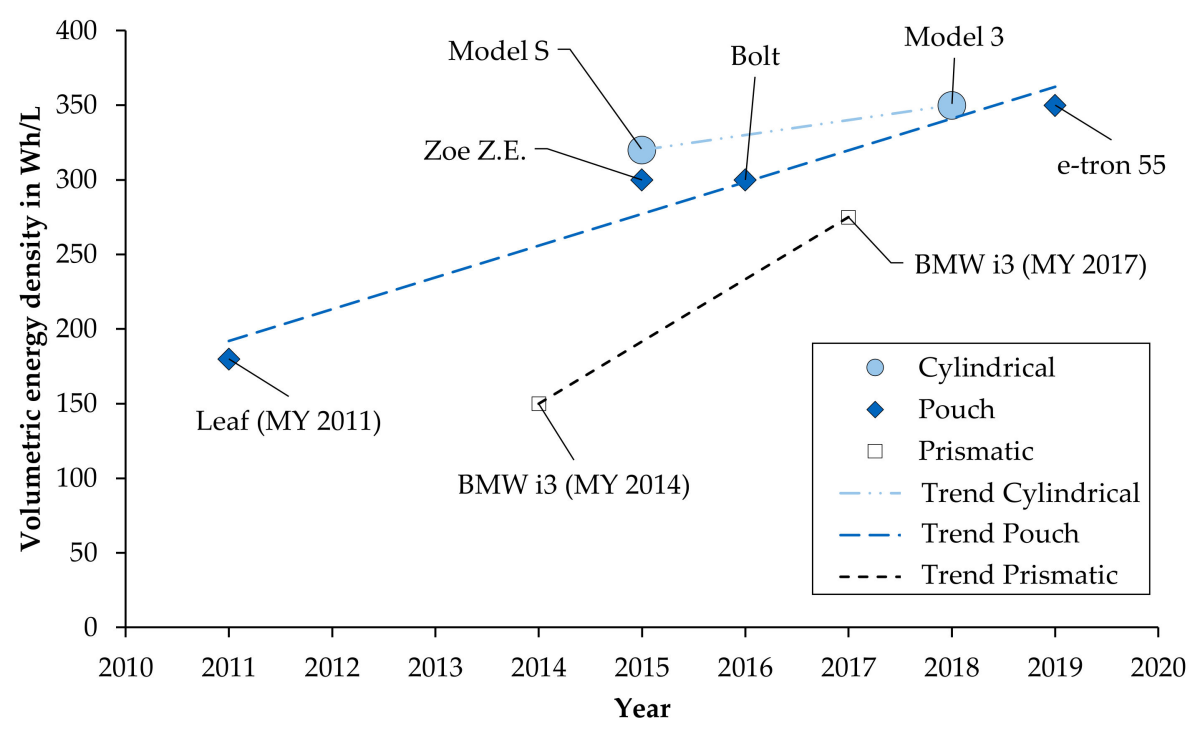

Figure 5. Overview of the volumetric energy density at the pack level for different BEVs.

Figure 4 shows an assessment of gravimetric energy density at the pack level based on vehicle data taken from [15,26-28].

Figure 5 shows an assessment of volumetric energy density at the pack level. In this case, the amount of data available is smaller, and the only possible source are the values listed in [15].

A forecast of energy densities at the pack level (both gravimetric and volumetric) for the years 2025 and 2030 can be found in the report by Thielmann et al. [19]. However, this report does not consider the possibility of a cell-to-pack strategy.

To increase battery lifetime, the installed energy is normally not used up in its entirety [26]. It is therefore necessary to distinguish between installed (gross) energy, and actually usable (net) energy. Since the values listed in Figures 4 and 5 refer to gross energy, we derive a conversion factor to estimate the net energy from the gross value. 
For this purpose, $26 \mathrm{BEVs}$ from the ADAC database [29] are evaluated; Figure 6 presents the gross energy for each vehicle along with the corresponding net value.

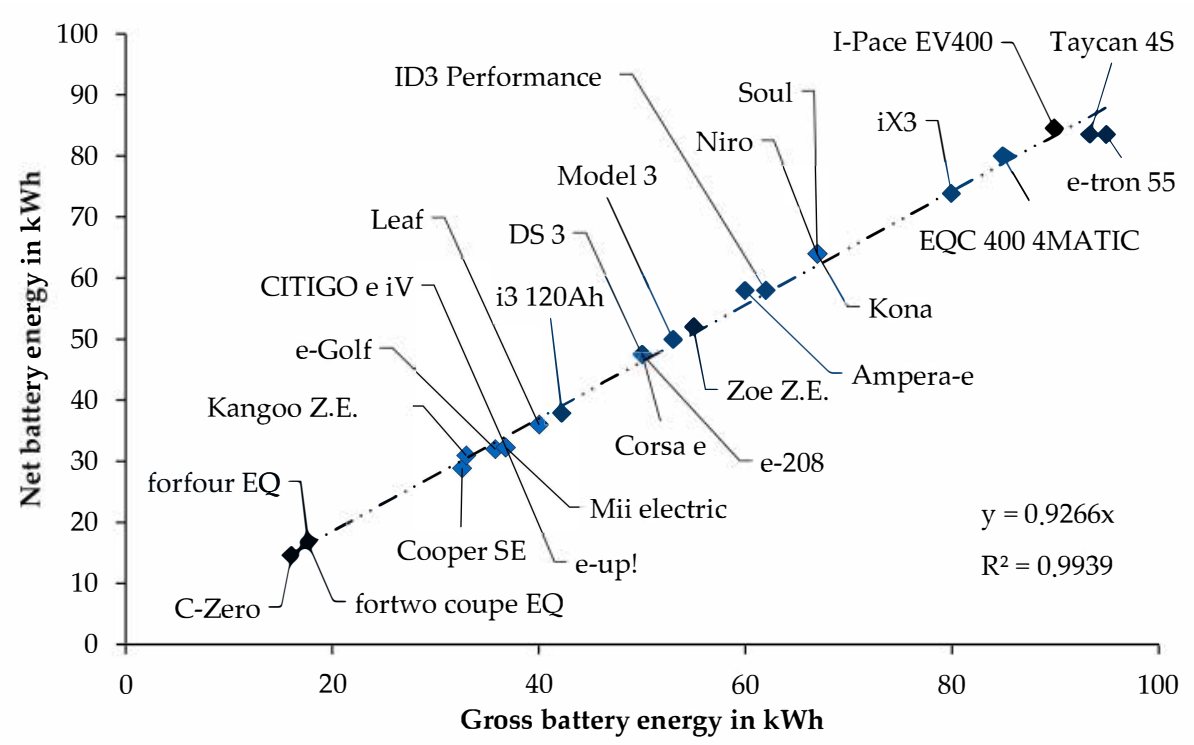

Figure 6. Comparison between gross and net energy for existing BEVs.

Using the method of the least squares, we derive the regression that best matches the vehicle data, as shown in Equation (1). The derived regression has an $R^{2}$ of 0.99. According to the equation, net energy can be approximated as $92 \%$ of gross energy. In addition to the energy densities at the pack and cell levels, other relevant battery parameters are the C-rate, the number of battery cycles, and battery costs:

$$
\text { Net energy in } \mathrm{kWh}=0.9266 \text { gross energy in } \mathrm{kWh}
$$

The C-rate (in 1/h) describes the maximum charge or discharge current in relation to the energy of the battery. It is necessary to distinguish between the C-rate for charging and discharging, whereby the latter is generally higher than the former [30]. A C-rate of 1 means that the battery can be completely discharged in one hour. According to the values proposed by $[10,15,26,30,31]$, we assume that, for the maximum C-rate, a range of between 2 and $5 \mathrm{~h}^{-1}$ is realistic for BEVs.

The number of battery cycles refers to the maximum number of cycles that the battery can endure before its useable energy drops to $80 \%$ of its initial value [31]. A range of between 1000 and 3000 cycles is considered realistic in the literature [11,12,15,22,31,32]. This range should be sufficient to guarantee a long battery life. Taking the lower value of the range (1000 cycles), as an example, a BEV with an electrical range of $200 \mathrm{~km}$ (which can nowadays be easily achieved by most car manufacturers) would still be able to cover a distance of 200,000 km before the battery's end of life (EOL). The required number of cycles is chosen according to the vehicle's range and distance aimed at by the time of the battery EOL.

There is a high observable variation in battery costs, since economies of scale can be triggered depending on the total number of vehicles produced $[33,34]$. Battery costs can therefore vary depending on the number of units produced (Table 2). 
Table 2. Overview of battery costs at pack level for different BEVs, based on [15].

\begin{tabular}{cccc}
\hline Vehicle & Model Year & Assumed Units Per Year & Pack Costs \\
\hline BMW i3 & 2014 & 15,000 & $396 € / \mathrm{kWh}$ \\
GM Bolt & 2016 & 20,000 & $224 € / \mathrm{kWh}$ \\
BMW i3 & 2017 & 25,000 & $254 € / \mathrm{kWh}$ \\
Renault Zoe & 2017 & 40,000 & $208 € / \mathrm{kWh}$ \\
Tesla Model 3 & 2018 & 100,000 & $164 € / \mathrm{kWh}$ \\
Audi e-tron & 2019 & 100,000 & $157 € / \mathrm{kWh}$ \\
\hline
\end{tabular}

In addition to state-of-the-art pack costs shown in Table 2, Figure 7 shows the derived range derived from the reviewed literature [5,11,34-39]. As current battery pack costs are already at the lower end of the reviewed range (indicated as "minimum values" in Figure 7), we also estimate the costs by 2030 to be in the lower range. Earlier studies overestimated the costs in 2020, which explains the increase in battery costs between the years 2019 and 2020, which represents the transition from real prices to forecasts. Furthermore, it is already possible to estimate the battery costs required to meet certain targets. For example, $91 € / \mathrm{kWh}$ is regarded as the economic limit, at which BEVs outperform ICEVs [11].

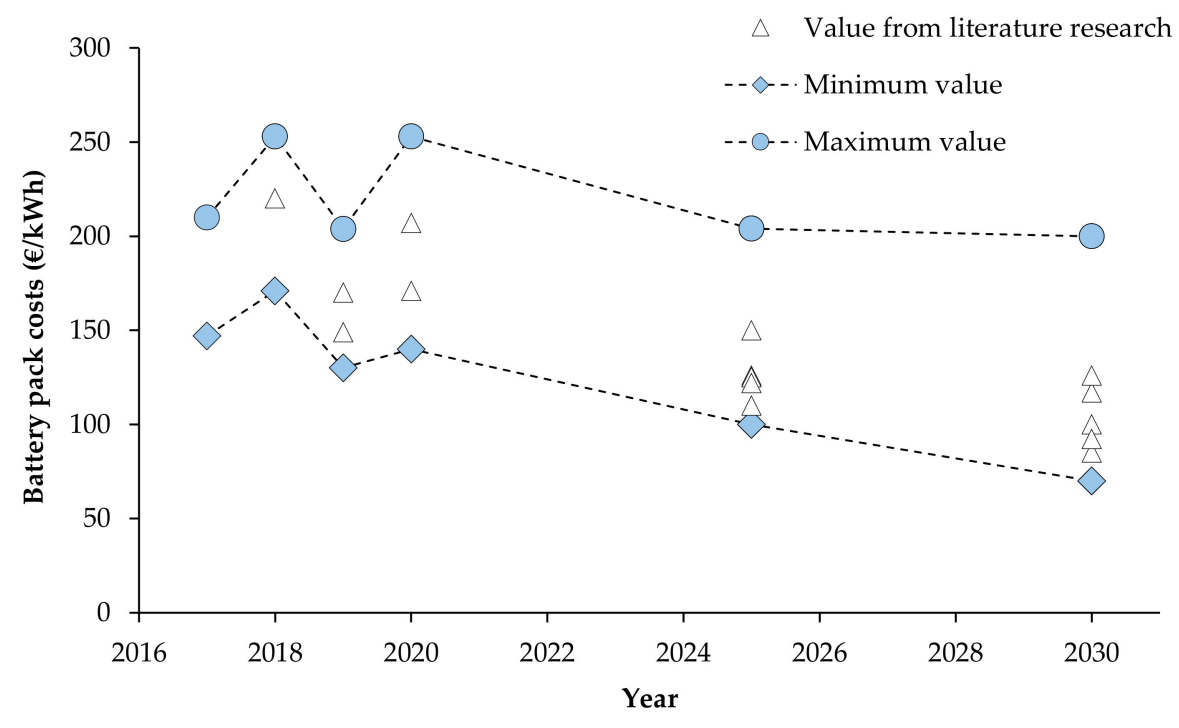

Figure 7. Development of battery pack costs (no distinction made between cell types).

Two common approaches for forecasting costs are top-down and bottom-up. Topdown approaches such as those taken by Cano et al. [35] or NPM [36] extrapolate current developments in battery prices to estimate future costs. In contrast, bottom-up approaches calculate the cell and respective pack costs based on material, labor, and overhead costs $[5,11,34,37-39]$. A well-known example of this approach is the battery manufacturing const estimation model (BatPac model) developed by the Argonne National Laboratory [40]. While such models offer great flexibility to account for the different battery types, several assumptions must be made about costs, which both increases uncertainty and decreases model flexibility.

An additional indicator in cost assessments is the cell-to-pack cost ratio (Table 3). This combines the additional component costs of a complete automotive battery pack, such as housing, cooling, and safety structures. By multiplying the cell costs with the cell-to-pack ratio, it is possible to estimate the corresponding pack costs. The literature review shows that this ratio is expected to decrease in the future, regardless of the cell type. This is primarily due to optimized production processes and cell chemistry bringing down cell costs. 
Table 3. Development of the cell-to-pack cost ratio based on [5,11,34-39].

\begin{tabular}{cccc}
\hline Year & $\mathbf{2 0 2 0}$ & $\mathbf{2 0 2 5}$ & $\mathbf{2 0 3 0}$ \\
\hline Minimum value & 1.94 & 1.47 & 1.17 \\
Maximum value & 2.21 & 1.32 & 1.24 \\
Mean value & 2.07 & 1.40 & 1.20 \\
\hline
\end{tabular}

Finally, another significant cost driver of cell production is the energy consumed during the manufacturing process [34]. This has a significant influence on the carbon dioxide emissions associated with lithium-ion battery production, which, along with costs, has been the focus of recent public debate [41]. While Romare and Dahllöf reported emissions of $150-200 \mathrm{kgCO}_{2 \mathrm{e}} / \mathrm{kWh}$ in the year 2015 [41], their update estimates a reduction in greenhouse gas emissions of between 61 and $106 \mathrm{kgCO}_{2 \mathrm{e}} / \mathrm{kWh}$ [42]. Their conclusion is based on the life-cycle assessment by Dai et al. who estimated that the greenhouse gas emissions for one automotive battery cell manufacturer are $73 \mathrm{kgCO}_{2 \mathrm{e}} / \mathrm{kWh}$ [43]. A sensitivity analysis of the supply chains performed by Kelly et al. confirms this range with $65 \mathrm{kgCO}_{2 \mathrm{e}} / \mathrm{kWh}$ as the best-case and $100 \mathrm{kgCO}_{2 \mathrm{e}} / \mathrm{kWh}$ for state-of-the-art supply chains [44]. Due to further optimization of cell chemistry, in turn, energy density could yield emissions below $50 \mathrm{kgCO}_{2 \mathrm{e}} / \mathrm{kWh}$, as forecasted by Philippot et al. [34].

\subsubsection{Electric Machine}

In our description of the electric machine, we focus on the following parameters:

- Gravimetric power density in $\mathrm{kW} / \mathrm{kg}$

- Machine overload factor

- Maximum rotational speed in $\mathrm{min}^{-1}$

- Costs in $€ / \mathrm{kW}$

Two common types are used in current BEV: permanent magnet synchronous machines (PSM) and induction motors (IM). The assessment by Grunditz [26] proposes a gravimetric power density range of between 1.7 and $3.7 \mathrm{~kW} / \mathrm{kg}$ for PSMs. Further improvements are expected in the future, since it is the objective of manufacturers to effect a continuous increase in power density [22]. According to Fireske [22], electric machine manufacturers aim to reach a value of $5 \mathrm{~kW} / \mathrm{kg}$, which is still some way off from the state-of-the-art range envisaged by Grunditz [26].

As for the machine overload factor, Kampker and Grunditz [10,26] propose a range of between 1 and 2 . The overload factor may vary according to the machine type or the manufacturer strategy and does not necessarily increase with the vehicle price bracket. For example, the Jaguar I-Pace has a ratio between nominal and maximum power of 1.66 [27], which is the same as that of the BMW i3 [45]. Nevertheless, an exact evaluation of the overload factor is difficult, since there is no standard definition of overload time (i.e., the maximum time during which the machine can remain in the overload area).

Finally, the maximum rotational speed of the electric machine may vary depending on the maximum speed of the vehicle and the gearbox transmission ratio [46]. At the moment, the maximum possible rotational speed range is between 9000 and $20,000 \mathrm{~min}^{-1}[10,26,47,48]$. In the future, the trend could shift towards higher rotational speeds (compensated for by a higher gearbox ratio), as recent discoveries [45] show that this can reduce the total weight of the driving unit, i.e., the higher weight of the gearbox (due to greater transmission ratio) can be compensated for by the reduction in electric machine weight (due to the lower required maximum torque).

The price of electric machines is depending on the nominal power. We differentiate between the PSM and an IM (Table 4). 
Table 4. Costs of electric machines.

\begin{tabular}{ccc}
\hline Machine Type & Price Per kW & Source \\
\hline PSM & $10 € / \mathrm{kW}$ & {$[5]$} \\
IM & $8 € / \mathrm{kW}$ & {$[5]$} \\
\hline
\end{tabular}

\subsubsection{Gearbox}

The gearbox is coupled with the electric machine and transmits the machine torque to the wheels. This requires a transmission ratio between torque and machine. In the case of BEVs, the electric machine is usually equipped with a gearbox with a fixed speed ratio $[49,50]$.There are currently only a few exceptions of BEVs with more than one speed (however these cannot be considered here), such as the Rimac Concept Two [51,52] and the Porsche Taycan.

The literature review shows that the gearbox ratio for BEVs with a fixed ratio varies within a range of 6 and $14[12,26,45,47,53,54]$. It is not possible to define an exact value since the required ratio depends on both the electric machine (torque and maximum rotational speed) and the desired maximum vehicle speed.

The presence of a gearbox causes further losses and thus increases vehicle consumption. These losses can be further assigned to the main gearbox components. It has to be further distinguished between losses that depend on the operating point (load dependent) and those that are independent from the operating point (load independent) [53] (pp. 69-71):

- Gears losses: friction losses (load dependent) and splash losses in the case of splash lubrication (load independent)

- Bearing losses: friction losses (load dependent) and lubrication losses (load independent)

- Losses due to sealing component

- Losses due to gearbox auxiliaries, such as the oil pumps

Due to the high variety of the gearbox losses, an exact modeling of the gearbox efficiency is very complicated and depends on the size and type of mounted component, as well as on the operating points (rotational speed and torque at the gearbox input shaft). For this reason, most of the reviewed authors usually employ a constant value, which accounts for the entire losses of the gearbox unit. The literature shows that BEV gearboxes can achieve high efficiencies, partly due to their small dimensions and the small number of rotating parts. The identified gearbox efficiency range between $92 \%$ and $97 \%[47,53,55,56]$.

\subsubsection{Power Electronics}

The efficiency of the power electronics influences both vehicle consumption and the required battery capacity. It is not possible to give an exact value, since the efficiency of the power electronics varies according to its operation conditions (e.g., input power or battery voltage [48], or torque and rotation speed [57], see Figure 8). Especially with low torque and motor speed, the efficiency is reduced [58]. Nevertheless, the range of realistic power electronics efficiency values is between $85 \%$ and $95 \%[10,12,17,22,59]$.

\subsection{Glider}

When the powertrain components are removed from a vehicle, the remainder is referred to as a glider $[60,61]$. The glider comprises the body, chassis, low-voltage electrical components, exterior, and interior. A gilder price can be calculated either bottom-up or top-down. 


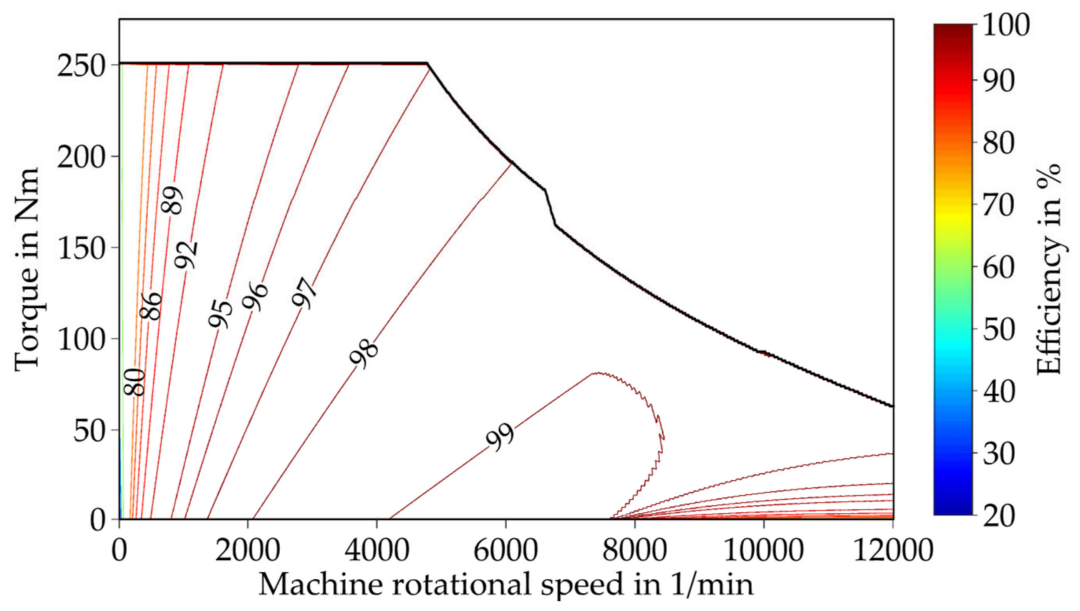

Figure 8. Efficiency map of a SiC MOSFET inverter [57].

To determine the glider price of an existing vehicle using the top-down approach, the production costs can be derived from the selling price by assuming a surcharge factor. The production costs (material + labor + depreciation) can be assumed to be around $60 \%$ of the selling price excluding taxes [62], which would correspond to a surcharge factor of 0.6 (Figure 9). After calculating the production costs of the total vehicle, the powertrain costs are deducted to obtain the glider production costs.

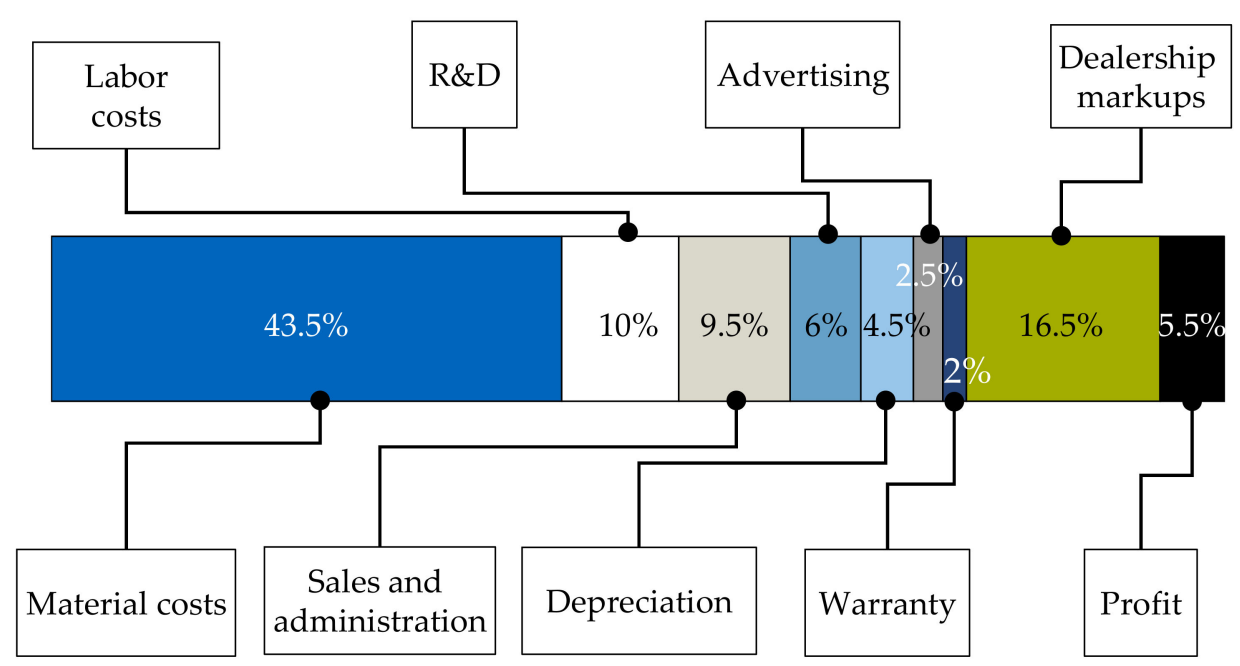

Figure 9. Cost breakdown for the net price of a new car [62].

To estimate glider costs using the bottom-up method, the single component costs are determined and totaled. Based on expert interviews [63] and data published in [5,9], we provide typical costs of a number of glider components (Table 5). We also provide costs of materials used for the body in white as well as for the interior. The costs can differ depending on optional preferences (e.g., LED headlights) and size of the car.

Table 5. Costs of standard equipment for a glider and for a medium-size car.

\begin{tabular}{ccc}
\hline Component & Costs & Source \\
\hline Windows & $75 €$ & {$[63]$} \\
Window lifter & $12 €$ & {$[63]$} \\
Exterior lights & $140 €$ & {$[63]$} \\
Low-voltage electronics (excluding wiring harness) & $520 €$ & {$[5]$} \\
\hline
\end{tabular}


Table 5. Cont.

\begin{tabular}{ccc}
\hline Component & Costs & Source \\
\hline Wiring harness & $210 €$ & {$[5]$} \\
ESP & $160 €$ & {$[5]$} \\
Airbag & $20 €$ & {$[63]$} \\
HVAC & $80 €$ & {$[63]$} \\
Seat warmer & $10 €$ & {$[63]$} \\
Windshield wiper & $30 €$ & {$[63]$} \\
Front seat & $100 €$ & {$[63]$} \\
Body in white and exterior (ICEV) & $1700 €$ & {$[9]$} \\
Body in white and exterior (BEV) & $2100 €$ & {$[9]$} \\
\hline Material & Specific Costs & Source \\
\hline Aluminum & $2,5-4 € / \mathrm{kg}$ & {$[63]$} \\
High-strength steel & $0.6-1 € / \mathrm{kg}$ & {$[63]$} \\
Plastic PP & $1.6-2 € / \mathrm{kg}$ & {$[63]$} \\
Plastic ABS & $2.5-3.5 € / \mathrm{kg}$ & {$[63]$} \\
\hline
\end{tabular}

\subsection{Components for Autonomous Vehicles}

Vehicle automation is one of the great challenges that manufacturers are addressing. In addition to technical hurdles, changes in society and legislation are necessary to enable the acceptance of higher levels of automation. Although autonomous driving promises improved comfort, safety, and running costs, the associated acquisition and development costs are high [64]. The sensors and computers it requires are currently expensive, and it is still being discussed as to what components should be integrated in the AV and which in the infrastructure [2]. Furthermore, companies and researchers use different setups with different sensor types in their vehicles [64]. The selection of sensors and computer unit thus depends on the envisaged scenario and the vehicle configuration to be specified by the manufacturer.

For the above reasons, determining the cost of autonomous vehicles is a challenging task. We therefore decided only to provide the costs of components already in use in mass production vehicles and prototypes and to refrain from estimating the costs of the complete sensor setup.

Radar, cameras, and ultrasonic sensors are already used in mass production. Lidar and computing platforms will continue to adapt in the coming years as they have only just started to go into mass production but are currently already found primarily in concept and research cars. In addition to mechanical sensors with several channels, a number of promising solid-state sensors are being developed for use in future series production. Current prices given in various press releases, on manufacturer websites, and in internet articles [65-71] reveal a high range of variation (of between $88 €$ and 67,250€). Since most of them have a low production volume and the actual prices will be highly dependent on technical characteristics and production volumes, the price we assume is that of the current ScaLa I Lidar by Valeo [72], which, to our knowledge, is the only one used in mass production.

The costs of the aforementioned lidar sensor together with the radar, camera, and ultrasonic sensors are shown in Table 6. These have been collected from expert interviews [63] in the context of current series production vehicles. The price of the central computer is an average value, based on several computers capable of autonomous level 2 and $3[73,74]$.

Although computers for higher levels of automation require higher performance and redundancy levels, their prices will drop due to increased production volume and further future development. For example, the price of the HW 3 computer used in the Tesla Model 3 is about $20 \%$ lower than that of the previous generation, the HW2.5 [74]. 
Table 6. Overview of sensor costs (Level 2-Level 3).

\begin{tabular}{ccc}
\hline Component & Costs & Source \\
\hline Lidar Sensor & $540 €$ & {$[72]$} \\
Radar Sensor & $90 €$ & {$[63]$} \\
Camera & $25 €$ & {$[63]$} \\
Triple-Camera & $60 €$ & {$[74]$} \\
Ultrasonic Sensor & $5 €$ & {$[63]$} \\
Computer & $680 €$ & {$[73,74]$} \\
\hline
\end{tabular}

The costs and parameters presented above refer only to the vehicle itself. However, the vehicle is only one aspect of an overall mobility system for which multiple costs and parameters have to be taken into consideration (see Section 3).

\section{Mobility}

A person's mobility costs can be divided into those costs relating to a privately-owned vehicle (Section 3.1) and the costs of the public mobility services used (Section 3.2). For the former, the approximate costs can be determined by a total cost of ownership (TCO) calculation. Public service costs, on the other hand, have to be calculated using a pricebased approach based on charges set by the individual service provider. In the following, the prices of such services are given for the city of Munich. However, the BEV powertrain will bring about radical changes in mobility behavior, generating new relevant parameters that need to be assessed (Section 3.3).

\subsection{Vehicle Use and Total Cost of Ownership (TCO)}

Tables A1 and A2 in Appendix A present the parameter values of a TCO calculation for privately-owned passenger cars, bicycles, pedelecs, scooters, and motorcycles. The annual costs shown in Tables A1 and A2 are based on annual mileage and the holding period of the vehicle. We assume an annual mileage of $15,000 \mathrm{~km}$ and a holding period of five years. Explanations of the calculation methods and the sources of the cost factors are given in Table A3.

Due to the large environmental bonus for plug-in hybrid vehicles (PHEVs) and BEVs granted by the German government, these vehicles are already competitive in terms of TCO compared to the conventional powertrains in petrol- or diesel vehicles (Figure 10). Fuel cell electric vehicles (FCEV) cause about $60 \%$ more annual costs in 2020, due to their higher acquisition price.

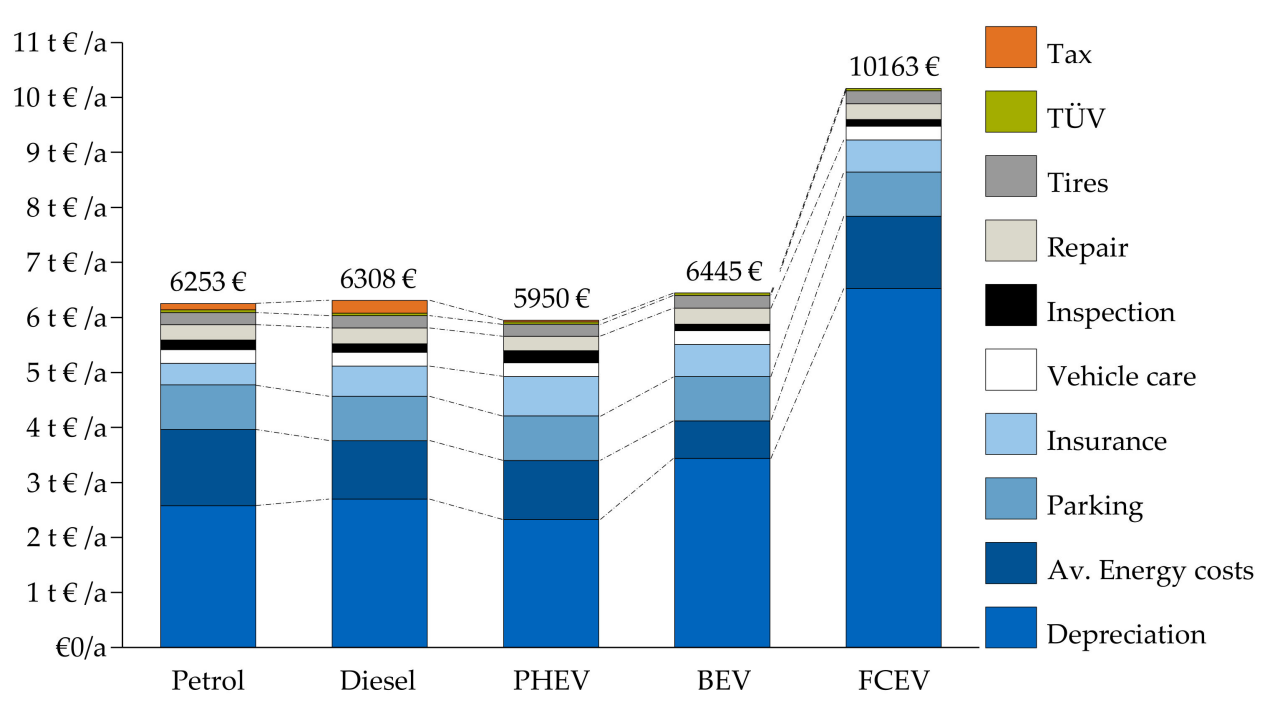

Figure 10. TCO per year for small SUVs based on 15,000 km per year and a five-year period of ownership in 2020. 
For PHEVs, two different cases are defined (Figure 11) whose charging behaviors significantly impact the costs and emissions of the vehicle. The PHEV (empty battery) curve reflects the more realistic scenario of a battery not being fully charged prior to each trip.

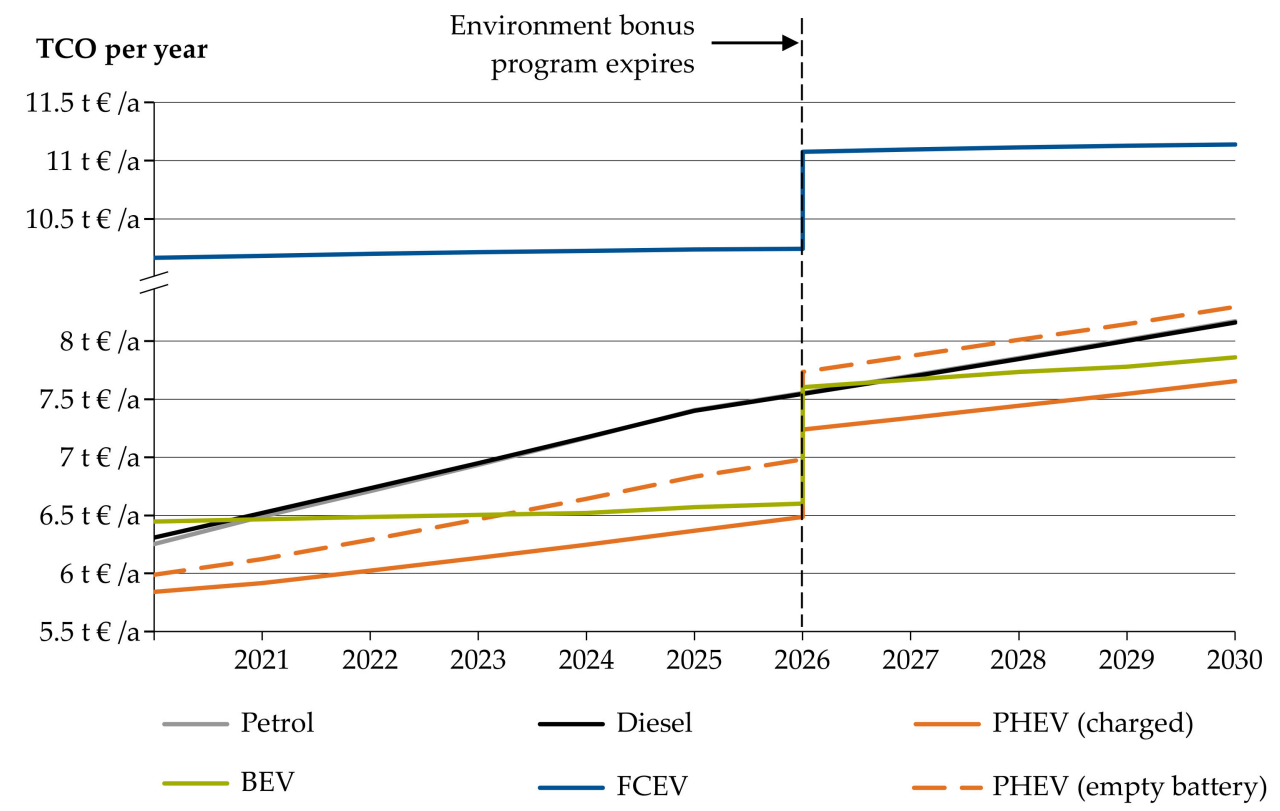

Figure 11. TCO per year relative to time of purchase for small SUVs at 15,000 km per year with a five-year period of ownership.

The forecast is based on energy cost predictions (cf. Section 5) and the expected development of component costs for electrified vehicles (cf. Section 2). Expected inflation leads to slightly increasing curves for all types of powertrains. At the same time, the costs of BEV and PHEV components like the traction battery, electric machines, and power electronics are decreasing and thus flattening the inflation gradient. The environment bonus expires in 2026, by which time BEV will have achieved cost parity with conventional powertrains without a bonus. According to the forecast shown in Figure 11, PHEV (empty battery) and FCEVs will be still more expensive than BEVs after 2026.

The TCO does not represent a fixed variable, so Figure 11 shows the expected TCO development for different powertrain types on the basis of an example small SUV with an annual mileage of $15,000 \mathrm{~km}$ and a five-year period of ownership.

\subsection{Mobility Services}

Table A4 sets out the prices of various service-based transport modes in Munich, including conventional public transport services (subway train, streetcar, and bus) provided by MVV [75]. The MVV (Münchner Verkehrs- und Tarifverbund) coordinates all public transport providers in the metropolitan region of Munich. All sharing concepts have a price system that is either time or distance based. In addition, some providers have a minimum fare that has to be covered, while taxis also charge for time spent waiting in traffic. The MVV offers different types of tickets for public transport. Table A4 shows the consumer costs per ride and year for the example scenario of rides within Zone M ( 2 rides per day, 7 days a week, 50 weeks a year).

Table A4 also includes a further variable: average transport speed. This variable creates a correlation between price per minute and price per kilometer (see Table A4). For the purposes of this paper, we use an average speed within Munich and its region that was derived from tracking devices installed in taxis (Figure 12). 


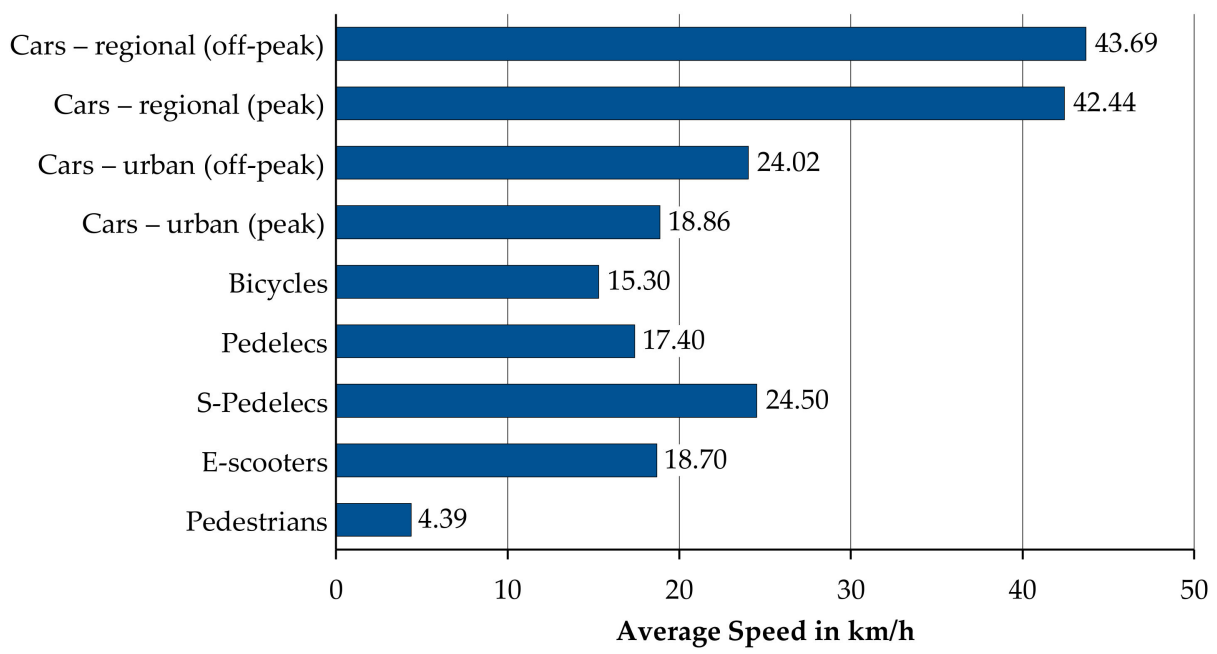

Figure 12. Average speed values for different transport modes in Munich [76-87].

Future technologies such as AVs will offer new business cases to conventional mobility services, such as autonomous taxis and buses. Table 7 lists cost data for automated driving services. The table distinguishes between individual and shared mode. The individual mode of automated driving service is comparable to a conventional taxi without a driver (Robo-Taxi) while the shared mode is similar to a bus shuttle service excluding the costs of a driver. The costs per vehicle per $\mathrm{km}$ represent the cost per $\mathrm{km}$ when there is only one passenger, while the costs per person per $\mathrm{km}$ are based on certain vehicle occupancies (average numbers of passengers per ride), as defined in the various studies.

Table 7. Summary of forecast values for automated driving services (taxi, e-hailing, bus, etc.).

\begin{tabular}{cccccc}
\hline Vehicle Type & Year & Costs Per Vehicle Per km & Costs Per Person Per km & Mode & Source \\
\hline Midsize (regional) & 2017 & $0.33 € / \mathrm{km}$ & $0.29 € / \mathrm{km}$ & Individual & {$[76]$} \\
Midsize (urban) & 2017 & $0.45 € / \mathrm{km}$ & $0.37 € / \mathrm{km}$ & Individual & {$[76]$} \\
Car-not specified & $\mathrm{n} / \mathrm{a}$ & $\mathrm{n} / \mathrm{a}$ & $0.14 € / \mathrm{km}$ & Individual & {$[88]$} \\
Car-not specified & $\mathrm{n} / \mathrm{a}$ & $\mathrm{n} / \mathrm{a}$ & $0.11 € / \mathrm{km}$ & Individual & {$[88]$} \\
Small SUV & $2030-2035$ & $0.20 € / \mathrm{km}$ & $\mathrm{n} / \mathrm{a}$ & Individual & {$[89]$} \\
Large SUV & $2030-2035$ & $0.22 € / \mathrm{km}$ & $\mathrm{n} / \mathrm{a}$ & Individual & {$[89]$} \\
Microtransit vehicle & 2030 & $\mathrm{n} / \mathrm{a}$ & $0.07 € / \mathrm{km}$ & Shared & {$[90]$} \\
Car-not specified & $2020-2030$ & $0.11 € / \mathrm{km}$ & $\mathrm{n} / \mathrm{a}$ & Individual & {$[91]$} \\
Car-not specified & $\mathrm{n} / \mathrm{a}$ & $0.25-0.27 € / \mathrm{km}$ & Individual & [92] \\
\hline
\end{tabular}

\section{External Costs}

A holistic view of mobility costs should not only consider costs to the consumer but also external costs. According to [93-96], external costs can be subdivided into the following subcategories:

- Climate costs: Costs attributable to the emission of greenhouse gases and the resulting climate change (damage cost approach).

- Air pollution: Environmental costs resulting from the emission of air pollutants incurred in the form of health care costs, crop losses, damage to buildings and materials, and biodiversity loss.

- Up- and downstream processes: Follow-on costs due to the emission of greenhouse gases and air pollutants from the production, maintenance, and disposal of: energy sources (fuels, electricity), vehicles, and transport infrastructure.

- Accident costs: Traffic accidents (damage cost rate).

- Noise costs: Noise-related healthcare costs and costs attributable to noise pollution (damage costs). 
- Nature and landscape: Habitat losses (through land consumption) and habitat fragmentation.

Table 8 shows the sum of external costs for different transport modes.

Table 8. External costs for various transport modes.

\begin{tabular}{ccc}
\hline Transport Mode & External Cost & Source \\
\hline Cars & $0.12 € / \mathrm{km}$ & EU (DG Move) [93] (p. 135) \\
Motorcycles & $0.25 € / \mathrm{km}$ & EU (DG Move) [93] (p. 135) \\
Public transport & $0.04 € / \mathrm{km}$ & Bieler and Sutter [94] \\
Bicycles & $-0.18 € / \mathrm{km}$ & Gössling et al. [95] \\
Walking & $-0.37 € / \mathrm{km}$ & Gössling et al. [95] \\
\hline
\end{tabular}

\subsection{Mobility Behavior}

BEV manufacturers must ensure that changing over from a conventional vehicle does not significantly restrict the mobility behavior of the user. For this reason, user movement data with conventional ICEVs is recorded to test whether a BEV already suits a customer's mobility needs. Even if the same distances can be covered with a BEV, some behavioral changes are required when changing over from an ICEV. The greatest change is the move from refueling to recharging, which is not considered in the aforementioned mobility data. The parameters given in Table 9 are intended to aid the consideration of new user needs in the development of a BEV.

Table 9. BEV mobility behavior parameters.

\begin{tabular}{|c|c|c|c|}
\hline Parameter & Description & Value & Source \\
\hline Lower SOC-limit & $\begin{array}{l}\text { Defined by unease due to remaining } \\
\text { range and end of comfort zone. }\end{array}$ & $15-25 \%$ or $50-100 \mathrm{~km}$ & [97-102] \\
\hline Upper SOC-limit & $\begin{array}{l}\text { Which SOC do users charge up to at } \\
\text { charging stations? }\end{array}$ & $\begin{array}{c}90-100 \% \text { (private, corporate) } \\
80 \% \text { [99] (public, charging } \\
\text { speed is reduced from } 80 \% \\
\text { SOC [103]) }\end{array}$ & {$[100,102,104]$} \\
\hline $\begin{array}{l}\text { Catchment area of } \\
\text { charging station }\end{array}$ & $\begin{array}{l}\text { Maximum distance from charging } \\
\text { station and actual location. Drivers } \\
\text { must travel the distance by car } \\
\text { separately and may have to walk } \\
\text { back to the actual location. }\end{array}$ & $100-500 \mathrm{~m}$ & [105] \\
\hline Minimal charging time & $\begin{array}{l}\text { Parking time, from which a charging } \\
\text { process is considered. }\end{array}$ & $5-15 \mathrm{~min}$ & {$[101,102]$} \\
\hline
\end{tabular}

\section{Infrastructure}

The electrification of road traffic is significantly dependent on the available charging infrastructure. Due to the lower ranges and higher refueling times of BEVs, companies and private individuals need to install a charging infrastructure on their premises. This adds further costs to the purchase and installation (Table 10).

Along with stationary charging, dynamic charging is another possible solution for increasing vehicle range. Dynamic charging refers to technologies that use various methods of energy transfer to charge the vehicle while driving. Current research focuses on conductive charging using overhead catenary wires, in-road conduction beams, and inductive charging with wireless power transfer. Since the first solution requires overhead cables mounted above the legal height limit of $4 \mathrm{~m}$, it is only suitable for heavy-duty vehicles or buses, as passenger cars would require a high pantograph to bridge the distance between roof and cables [107,108]. On the other hand, conductive charging with road conduction beams and inductive charging could potentially be shared among passenger and commer- 
cial vehicles. All three technologies share the additional infrastructure and the associated high costs that are shown in Table 11.

Table 10. Overview of costs of stationary charging infrastructure (business) [106].

\begin{tabular}{cccccc}
\hline Component & Cost Category & $\mathbf{1 1} \mathbf{k W}$ AC & $\mathbf{2 2} \mathbf{k W}$ AC & $\mathbf{2 4} \mathbf{k W} \mathbf{D C}$ & $\mathbf{5 0} \mathbf{k W} \mathbf{D C}$ \\
\hline \multirow{2}{*}{ Charging point $(\mathrm{CP})$} & Acquisition costs per CP & $1250 €$ & $1500 €$ & $15,000 €$ & $30,000 €$ \\
& Installation costs of base/per CP & & $1000 €+500 €$ per CP & $3500 €$ & $3500 €$ \\
Charge management & Acquisition and installation costs & $2500 €$ & $2500 €$ & $100 €$ & $100 €$ \\
\hline
\end{tabular}

Table 11. Cost of dynamic conductive and inductive charging infrastructures.

\begin{tabular}{ccccc}
\hline Cost Type & Investment Costs & Operational Costs & Additional Vehicle Costs ** & Source \\
\hline Catenary & $2-2.5 \sim \mathrm{M} € / \mathrm{km}^{*}$ & $1-2 \sim \%$ capex/year & $20,000-47,500 \sim €$ & {$[109]$} \\
Conductive & $0.5-1.2 \mathrm{M} € / \mathrm{km}^{*}$ & $1-2 \sim \%$ capex/year & $10,000 €+$ & {$[110]$} \\
Inductive & $2.6-3.6 \sim \mathrm{M} € / \mathrm{km}^{*}$ & $1-2.5 \sim \%$ capex/year & $10,000-10,800 €$ & {$[109,111]$} \\
\hline
\end{tabular}

${ }^{*}$ : per lane; ${ }^{* *}$ : refers to commercial vehicles, ${ }^{+}$: own assumption based on inductive system.

\section{Energy Costs}

Energy costs are a crucial aspect of economic assessment. As Figure 13 shows, a variety of taxes and levies to energy carriers exist in Germany, potentially resulting in prices that are 100-270\% higher than the respective production costs [36]. This wide range explains why taxes and subsidies (both highly regional) must be excluded when making technical comparisons. The costs given in Figure 13 are well-to-pump, which means that efficiency losses, for example in the powertrain, are not considered.

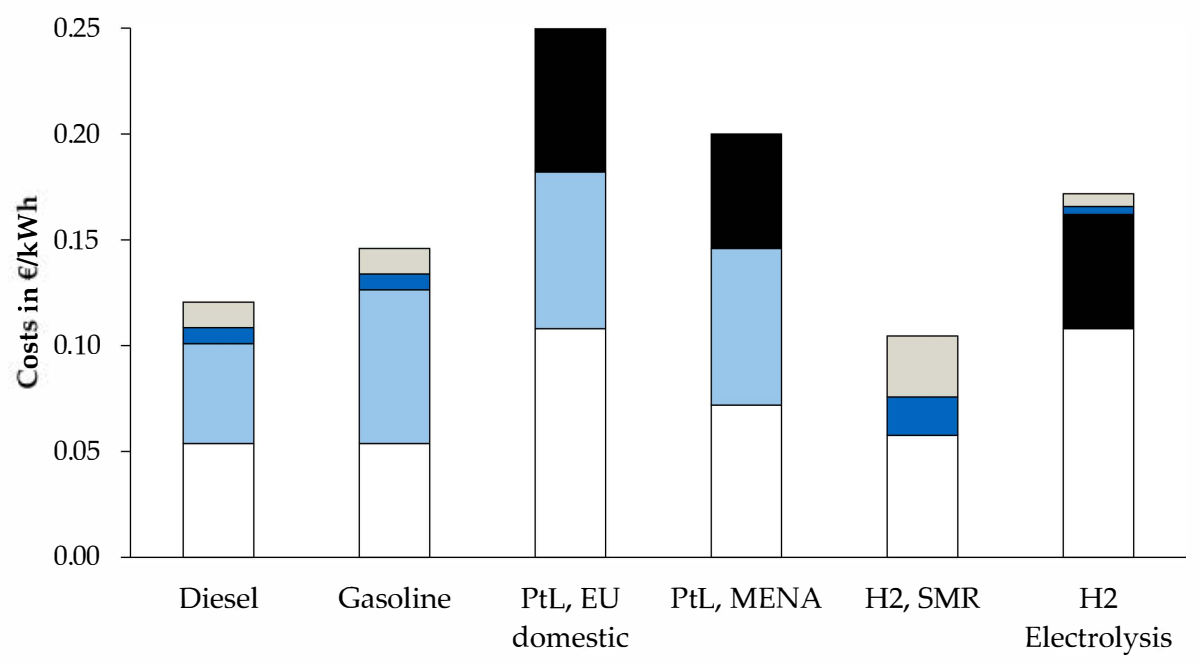

$\square$ Min. Climate Protecton Program 60€/tCO2

Range

Min. Climate Protecton Program 25€/tCO2

$\square$ Production Costs

Figure 13. Forecast for Germany. Normalized electricity and energy prices per kilowatt-hour for the year 2030 under current tax and subsidy policies [36,112]. Energy prices are also influenced by the German $\mathrm{CO}_{2}$ - tax at a minimum of $25 € / \mathrm{tCO}_{2}$ and a maximum of $65 € / \mathrm{tCO}_{2}$ [113].

With liquid fuels, for example, only energy taxes are levied, while, for electricity, in addition to taxes, there are also charges for the expansion of renewable energies under the German Renewable Energy Sources Act (German: Erneuerbare Energie Gesetz EEG) [112]. 
Starting from 2021, a $\mathrm{CO}_{2}$ tax of a minimum of $25 € / \mathrm{tCO}_{2}$ and a maximum of $65 € / \mathrm{tCO}_{2}$ will be introduced for fossil fuels in Germany [113], which will increase the total energy costs.

The ranges for hydrogen are subject to different production paths and production uncertainties, as these are not available on large scales. Currently, hydrogen is predominantly produced by a process of natural gas steam methane reforming (SMR) and is thus regarded as fossil (or grey) hydrogen, despite its relatively low primary energy demand. If green hydrogen is produced via electrolysis and renewable energy, carbon emissions can be reduced, although the costs of green hydrogen are higher than those of grey hydrogen due to electrolysis-losses (30\% losses) and the dependency of the process on electricity costs [114].

The power-to-liquid (PtL) ranges have the same origins as hydrogen fuels. The production chain for PtL fuels begins with hydrogen and $\mathrm{CO}_{2}$-extraction to form hydrocarbon chains. Further possible process steps are methanization or liquification by Fischer-Tropsch synthesis [114]. However, additional losses (30\%) in the liquification processes require twice as much primary energy as for electrolysis alone (and up to four times as much, if the well-to-wheel efficiency is considered) [115]. Thus, PtL processes are also strongly dependent on electricity prices and therefore divided into two regions based on different price assumptions: (1) domestic EU production $(0.09 € / \mathrm{kWh})$ and (2) production in the Middle East or North Africa (MENA) with lower electricity prices (0.03-0.06 €/kWh) [115].

Since both hydrogen and PtL production costs depend heavily on electricity prices, a uniform system boundary is essential. The study by the German Energy Agency (German: Deutsche Energieagentur DENA) lists costs of PtL fuels and hydrogen for different countries or regions of origin [116]. Purchase costs in Germany are shown in Table 12. As they have the same fuel supply, these costs are transferable to other European or global countries, although individual taxation may vary. It also shows the electricity generation costs (i.e., the costs of creating a new energy infrastructure) of renewable energy as proposed by Kost and Schlegl [117].

Table 12. Current (2020) and projected (2030) production costs of various energy sources normalized to $€_{2020} / \mathrm{kWh}$. As there is no current large-scale production of power-to-liquid and hydrogen from electrolysis, no data are available for 2020 [36,115-117]. (Note: MENA: Middle East, North Africa).

\begin{tabular}{ccccccccc}
\hline Year & $\begin{array}{c}\text { Gasoline } \\
\text { and Diesel }\end{array}$ & $\begin{array}{c}\text { Power to } \\
\text { Liquid, } \\
\text { Domestic }\end{array}$ & $\begin{array}{c}\text { Power-to- } \\
\text { Liquid, } \\
\text { MENA }\end{array}$ & $\begin{array}{c}\text { SMR } \\
\text { Hydrogen }\end{array}$ & $\begin{array}{c}\text { Electrolysis } \\
\text { Hydrogen, } \\
\text { Domestic }\end{array}$ & $\begin{array}{c}\text { Electrolysis } \\
\text { Hydrogen, } \\
\text { MENA }\end{array}$ & $\begin{array}{c}\text { Electricity } \\
\text { mix }\end{array}$ & $\begin{array}{c}\text { Renewable } \\
\text { Electricity }\end{array}$ \\
\hline 2020 & 0.046 & 0.855 & $\mathrm{n} / \mathrm{a}$ & 0.26 & $\mathrm{n} / \mathrm{a}$ & $\mathrm{n} / \mathrm{a}$ & 0.105 \\
2030 & 0.054 & 0.307 & 0.121 & 0.058 & 0.121 & 0.074 & 0.121 & 0.061 \\
\hline
\end{tabular}

\section{International Carbon-Dioxide Prices}

Carbon pricing is one of the currently discussed levers to push the economy towards less carbon-dioxide emissions. This applies not only for fossil fuels, as discussed above, but also for the energy production sector and is thus of importance when comparing different powertrains and electric vehicles in particular. Although several countries introduced carbon pricing, the strategies vary [118]. China, the EU, and parts of the USA have a certificate-based trading system yielding a dynamic, demand-and-supply oriented pricing - also referred to as cap-and-trade. In contrast, Switzerland and Sweden are examples of taxation with defined rates that were increased during the past decades [119]. Table 13 shows an overview of selected, current carbon-dioxide prices and their respective introduction years. It must be noted that, despite many countries adopting some measure of $\mathrm{CO}_{2}$-price, the eventual price and thus effect on greenhouse gas reduction vary.

Figure 14 shows the different introduction years and the two pricing mechanisms. The data suggests that demand-and-supply did not result in a markable increase of the $\mathrm{CO}_{2}$-price, while the governmentally controlled Swedish carbon tax increased from $25 €$ in 1991 to $116 €$ today [120]. The excessive disbursement of the European ETS certificates 
between 2012 and 2017 resulted in a stagnating carbon price at low levels [121]. Shorting the certificates in 2018 lead to a price increase that stabilized at 2007 levels [122]. The steadily decreasing emission allowances in California (cap) lead to a steady increase in $\mathrm{CO}_{2}$-price [123]. Sweden increased taxes with a fixed rate while California, EU ETS, and China use trading systems $[120,121,124,125]$. The Chinese trading system is still in use, but no consecutive data are available.

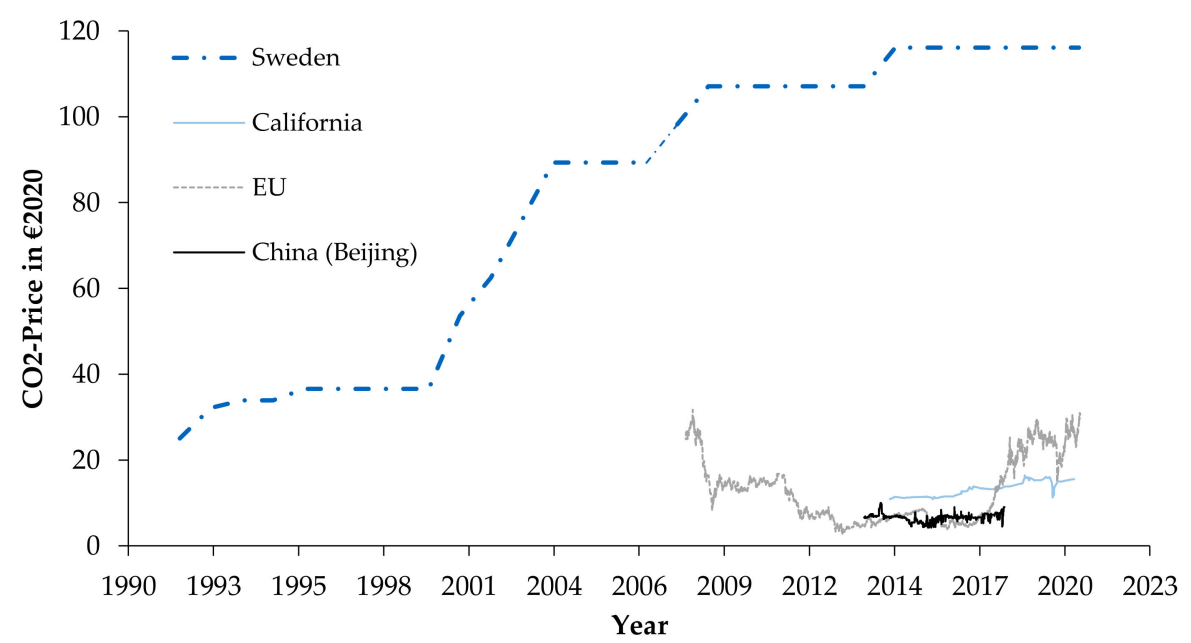

Figure 14. Historic development of selected international carbon prices.

Table 13. Overview of international $\mathrm{CO}_{2}$-taxes and certificates in $€_{2020}$ and the respective introduction year [119,126-128].

\begin{tabular}{ccc}
\hline Price in $\boldsymbol{€} / \mathbf{t} \mathbf{C O}_{\mathbf{2}}$ & Introduction & Country \\
\hline 10.5 & 2008 & China (Bejing) \\
0.99 & 2015 & China (Shenzen) \\
$25-60$ & 2003 & Germany \\
44.6 & 2014 & France \\
20 & 2013 & Great Britain \\
2.4 & 2012 & Japan \\
10.2 & 2019 & Canada \\
0.07 & 1990 & Poland \\
112 & 1991 & Sweden \\
87 & 2018 & Switzerland \\
7.7 & 2019 & South Africa \\
20 & 2015 & South Korea \\
15.5 & 2013 & USA (California) \\
5 & 2009 & USA (RGGI *) \\
\hline
\end{tabular}

* RGGI: Regional Greenhouse Gas Initiative includes the states of Connecticut, Delaware, Maine, Maryland, Massachusetts, New Hampshire, New Jersey, New York, Rhode Island, Vermont, and Virginia.

In addition to trading systems, applicable $\mathrm{CO}_{2}$ limits and associated penalty payments can also be understood as $\mathrm{CO}_{2}$ prices. The European Union already set the penalty for exceeding passenger car and light-duty truck $(<3.5 \mathrm{t})$ emission to $95 \mathrm{\epsilon gCO}_{2} / \mathrm{km}$ [129]. Assuming a lifetime of 150,000 to $200,000 \mathrm{~km}$, this leads to $475-633 € / \mathrm{tCO}_{2}$. In the year 2019 , the European union also set $\mathrm{CO}_{2}$-limits for heavy-duty vehicles $(>3.5 \mathrm{t})$, targeting the road transport sector. The limits of $4250 €$ per gram $\mathrm{CO}_{2}$ and vehicle kilometer from 2025 to 2030 and $6300 € \mathrm{gCO}_{2} / \mathrm{tkm}$ onwards [130], take the vehicle payload—an important indicator in transportation-into account. Assuming a total mileage of one million kilometers and an average payload of $19.3 \mathrm{t}$ [131], the limits convert to $220 € / \mathrm{tCO}_{2}$ and $326 € / \mathrm{tCO}_{2}$, respectively. 


\section{Discussion and Outlook}

After discussing the megatrends of electrification and automation, we identified the changes they cause in the automotive industry, these being the new technical parameters, which are relevant due to the novel technologies required by BEVs and AVs, and the vehicle cost structures. The analysis focuses on the vehicle (Section 2), its mobility (Section 3), the required charging infrastructure (Section 4), and the corresponding energy costs (Section 5).

In terms of the vehicle, the high costs associated with BEVs compared to ICEVs still prevent many users from buying electric vehicles today. Another challenge is the vehicle range of BEVs, which is still not comparable to that available with ICEVs. Regarding vehicle costs, falling battery prices will lead to almost equal production costs by 2030 , resulting in comparable prices to customers without any subsidies. The range gap between $\mathrm{BEVs}$ and ICEVs is expected to decrease, as the literature review shows that an increase in gravimetrical and volumetric density can be expected at both cell and pack level. This may help reduce the fear of low ranges in the future, making BEVs more attractive for buyers.

Regarding mobility, the TCO assessment (Section 3.1) shows that BEVs are currently more expensive than ICEVs. Nevertheless, the forecast shows that, from 2026, the parity with ICEV can be reached and BEVs will be cheaper than other electrification solutions (such as PHEVs and FCEVs).

The charging infrastructure is, besides the vehicle itself, an important component of mobility. BEVs require a nationwide charging infrastructure to compensate for their current lower range compared to ICEVs. Dynamic charging could help on long distances without big batteries, but, in most cases, it is too expensive for passenger cars, especially in view of the rising energy densities of batteries.

Finally, with regard to energy costs, even if the production costs of fossil fuels are still lower than those of renewable electric energy, the higher efficiencies in the vehicle powertrain are an important advantage of BEVs.

In summary, the actual disadvantages of BEVs in comparison to other propulsion system are expected to decrease in the future thanks to technological developments and mass production. This could enable BEVs to develop into an optimal mobility solution.

Author Contributions: As the first authors, A.K. and L.N. defined the structure of the presented paper and each contributed 30\%. D.S. and S.W. contributed knowledge regarding mobility, infrastructure, and mobility and each contributed $20 \%$. A.W. provided us with compiled mobility data. M.L. made an essential contribution to the conception of the research project. He critically revised the paper for its important intellectual content. M.L. gave final approval of the version to be published and agrees to all aspects of the work. As a guarantor, he accepts responsibility for the overall integrity of the paper. All authors have read and agreed to the published version of the manuscript.

Funding: The research of A.K. was accomplished within the project "UNICARagil” (FKZ16EMO0288). We acknowledge the financial support for the project from the Federal Ministry of Education and Research of Germany (BMBF). The research of L.N. was funded by the AUDI AG and the Technical University of Munich. The research of D.S. and S.W. was conducted with basic research funds of the Technical University of Munich.

Acknowledgments: The author L.N. would like to thank the colleagues of the AUDI AG in the persons of Maximilian Heinrich, Martin Abersmeier, and Hendrik Gronau.

Conflicts of Interest: The authors declare no conflict of interest, and the funders had no role in the design of the study; in the collection, analyses, or interpretation of data; in the writing of the manuscript; or in the decision to publish the results. 


\section{Appendix A}

Table A1. Average values for TCO calculation with a holding period of five years and a 15,000 km annual mileage.

\begin{tabular}{|c|c|c|c|c|c|c|c|c|c|c|c|c|}
\hline $\begin{array}{c}\text { Vehicle } \\
\text { Segment }{ }^{1,2}\end{array}$ & $\begin{array}{l}\text { Acquisition } \\
\text { Bonus }\end{array}$ & $\begin{array}{c}\text { Environment } \\
\text { Bonus }^{3}\end{array}$ & Depreciation $^{4}$ & Insurance & Tax & TÜV & Maintenance & Repair & Tires & Parking & Vehicle Care & $\begin{array}{l}\text { Consumption } \\
\text { per } 100 \mathrm{~km}\end{array}$ \\
\hline Small Petrol & $15,090 €$ & $0 €$ & $1427 €$ & $437 €$ & $82 €$ & $44 €$ & $180 €$ & $252 €$ & $179 €$ & $805 €$ & $250 €$ & 5.91 \\
\hline Small BEV & $24,771 €$ & $9570 €$ & $1437 €$ & $415 €$ & $0 €$ & $44 €$ & $108 €$ & $204 €$ & $218 €$ & $805 €$ & $250 €$ & $14.3 \mathrm{kWh}$ \\
\hline Med. Petrol & $21,921 €$ & $0 €$ & $2073 €$ & $492 €$ & $87 €$ & $44 €$ & $180 €$ & $276 €$ & $176 €$ & $805 €$ & $250 €$ & 6.51 \\
\hline Med. BEV & $36,241 €$ & $9570 €$ & $2522 €$ & $474 €$ & $0 €$ & $44 €$ & $96 €$ & $288 €$ & $259 €$ & $805 €$ & $250 €$ & $15.4 \mathrm{kWh}$ \\
\hline Large Petrol & $33,345 €$ & $0 €$ & $3153 €$ & $495 €$ & $178 €$ & $44 €$ & $180 €$ & $288 €$ & $246 €$ & $805 €$ & $250 €$ & 7.61 \\
\hline Large Diesel & $34,902 €$ & $0 €$ & $3300 €$ & $563 €$ & $263 €$ & $44 €$ & $156 €$ & $300 €$ & $246 €$ & $805 €$ & $250 €$ & 5.81 \\
\hline Large PHEV & $38,639 €$ & $5981 €$ & $3088 €$ & $545 €$ & $0 €$ & $44 €$ & $288 €$ & $300 €$ & $252 €$ & $805 €$ & $250 €$ & $3.81+8.3 \mathrm{kWh}^{5}$ \\
\hline Large BEV & $54,972 €$ & $7975 €$ & $4443 €$ & $895 €$ & $0 €$ & $44 €$ & $228 €$ & $252 €$ & $283 €$ & $805 €$ & $250 €$ & $18.5 \mathrm{kWh}$ \\
\hline SUV Petrol & $27,290 €$ & $0 €$ & $2580 €$ & $390 €$ & $140 €$ & $44 €$ & $180 €$ & $276 €$ & $223 €$ & $805 €$ & $250 €$ & $7.11^{\circ}$ \\
\hline SUV Diesel & $28,564 €$ & $0 €$ & $2701 €$ & $549 €$ & $240 €$ & $44 €$ & $156 €$ & $288 €$ & $223 €$ & $805 €$ & $250 €$ & 6.21 \\
\hline SUV PHEV & $31,546 €$ & $7178 €$ & $2304 €$ & $721 €$ & $2 €$ & $44 €$ & $216 €$ & $264 €$ & $217 €$ & $805 €$ & $250 €$ & $3.81+7.3 \mathrm{kWh}^{5}$ \\
\hline SUV BEV & $44,949 €$ & $9570 €$ & $3345 €$ & $582 €$ & $0 €$ & $44 €$ & $120 €$ & $288 €$ & $235 €$ & $805 €$ & $250 €$ & $17.2 \mathrm{kWh}$ \\
\hline SUV FCEV & $76,139 €$ & $7975 €$ & $6445 €$ & $582 €$ & $144 €$ & $44 €$ & $120 €$ & $288 €$ & $235 €$ & $805 €$ & $250 €$ & $0.9 \mathrm{~kg}$ \\
\hline M-cycle Pet. & $16,035 €$ & $0 €$ & $1525 €$ & $568 €$ & $88 €$ & $33 €$ & & $725 €$ & & $0 €$ & $0 €$ & 4.751 \\
\hline M-cycle BEV & $22,170 €$ & $0 €$ & $2108 €$ & $568 €$ & $0 €$ & $33 €$ & & $725 €$ & & $0 €$ & $0 €$ & $9.2 \mathrm{kWh}$ \\
\hline
\end{tabular}

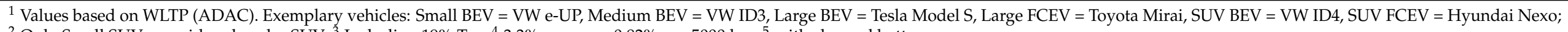

${ }^{2}$ Only Small SUVs considered under SUV; ${ }^{3}$ Including $19 \%$ Tax; ${ }^{4} 3.3 \%$ per year; $0.82 \%$ per $5000 \mathrm{~km} ;{ }^{5}$ with charged battery

Table A2. Average values for TCO calculation with a holding period of five years and $2000 \mathrm{~km}$ annual mileage.

\begin{tabular}{|c|c|c|c|c|c|c|c|c|c|c|c|c|}
\hline $\begin{array}{l}\text { Vehicle } \\
\text { Segment }\end{array}$ & $\begin{array}{l}\text { Acquisition } \\
\text { Bonus }\end{array}$ & $\begin{array}{c}\text { Environment } \\
\text { Bonus }{ }^{1}\end{array}$ & Depreciation $^{2}$ & Insurance & Tax & TÜV & Maintenance & Repair & Tires & Parking & Vehicle Care & $\begin{array}{c}\text { Consumption } \\
\text { Per } 100 \mathrm{~km}\end{array}$ \\
\hline Bicycle & $420 €$ & $0 €$ & $47 €$ & $0 €$ & $0 €$ & $0 €$ & \multicolumn{2}{|c|}{$45 €$} & $18 €$ & $0 €$ & $0 €$ & $\mathrm{n} / \mathrm{a}$ \\
\hline Pedelec & $2100 €$ & $0 €$ & $236 €$ & $0 €$ & $0 €$ & $0 €$ & \multicolumn{2}{|c|}{$55 €$} & $22 €$ & $0 €$ & $0 €$ & $0.73 \mathrm{kWh}$ \\
\hline S-Pedelec & $4607 €$ & $0 €$ & $517 €$ & $21 €$ & $0 €$ & $0 €$ & \multicolumn{2}{|c|}{$55 €$} & $22 €$ & $0 €$ & $0 €$ & $0.73 \mathrm{kWh}$ \\
\hline Scooter Pet. & $3520 €$ & $0 €$ & $226 €$ & $21 €$ & $0 €$ & $0 €$ & $\mathrm{n} / \mathrm{a}$ & $\mathrm{n} / \mathrm{a}$ & $\mathrm{n} / \mathrm{a}$ & $\mathrm{n} / \mathrm{a}$ & $\mathrm{n} / \mathrm{a}$ & 2.91 \\
\hline Scooter BEV & $6220 €$ & $0 €$ & $399 €$ & $21 €$ & $0 €$ & $0 €$ & $\mathrm{n} / \mathrm{a}$ & $\mathrm{n} / \mathrm{a}$ & $\mathrm{n} / \mathrm{a}$ & $\mathrm{n} / \mathrm{a}$ & $\mathrm{n} / \mathrm{a}$ & $3.5 \mathrm{kWh}$ \\
\hline E-Scooter ${ }^{3}$ & $799 €$ & $0 €$ & $145 €$ & $21 €$ & $0 €$ & $0 €$ & $\mathrm{n} / \mathrm{a}$ & $\mathrm{n} / \mathrm{a}$ & $\mathrm{n} / \mathrm{a}$ & $\mathrm{n} / \mathrm{a}$ & $\mathrm{n} / \mathrm{a}$ & $1.2 \mathrm{kWh}$ \\
\hline
\end{tabular}

${ }^{1}$ Including $19 \%$ Tax; ${ }^{2} 3.3 \%$ per year; $0.82 \%$ per $5000 \mathrm{~km} ;{ }^{3}$ The expected lifetime of an e-scooter is only around $7500 \mathrm{~km}$. 
Table A3. Explanation and sources for considered cost factors in TCO calculation.

\begin{tabular}{|c|c|c|}
\hline Cost Considered & $\begin{array}{c}\text { Description of Approach for Passenger Cars } \\
\text { and Motorized } \\
\text { Scooters/Motorcycles }\end{array}$ & Main Source (s) \\
\hline Depreciation & $\begin{array}{c}\text { Average sales prices from Statista are utilized as } \\
\text { a baseline for each segment. Average MSRP } \\
\text { listings from ADAC are utilized to calculate } \\
\text { factors for the different propulsion types. } \\
\text { Market prices for an example vehicle are } \\
\text { researched for on various vehicle ages between } \\
0 \text { and } 10 \text { years and mileages between } 0 \text { and } \\
300,000 \mathrm{~km} \text {. }\end{array}$ & Statista [132], ADAC [133] \\
\hline Energy consumption & $\begin{array}{l}\text { Average fuel consumption values of vehicles } \\
\text { sold in the respective segment are used for petrol } \\
\text { and diesel ICEVs. Manufacturer specifications of } \\
\text { example vehicles are utilized for PHEV and BEV } \\
\text { fuel consumption. }\end{array}$ & $\begin{array}{c}\text { KBA [135], BMWi [136], MWV, } \\
\text { ADAC [133] }\end{array}$ \\
\hline Insurance & $\begin{array}{c}\text { Insurance costs are researched for each segment } \\
\text { and propulsion type depending on } \\
\text { annual mileage. }\end{array}$ & Check24.de [137] \\
\hline Tax & $\begin{array}{l}\text { Tax contributions are calculated on the basis of } \\
\text { the "Kraftfahrzeugsteuergesetz" regulation in } \\
\text { Germany and based on exemplary vehicle } \\
\text { specifications of frequently-sold vehicles. }\end{array}$ & KraftStG $2002[138,139]$ \\
\hline TÜV & Standard TÜV charge is assumed. & TÜV [140] \\
\hline Inspection and repair & $\begin{array}{l}\text { Values for inspection and repair are retrieved } \\
\text { from the ADAC online cost calculator for all } \\
\text { segments and propulsion types. }\end{array}$ & ADAC [141] \\
\hline Tires & $\begin{array}{l}\text { Summer and winter tire market prices are } \\
\text { retrieved for all segments and propulsion types. }\end{array}$ & Reifendirekt.de [142], DAT [143] \\
\hline Vehicle care & $\begin{array}{c}\text { Constant factor independent of assumed annual } \\
\text { mileage assumed. }\end{array}$ & ADAC [144] \\
\hline Parking & $\begin{array}{l}\text { Constant factor independent of assumed annual } \\
\text { mileage assumed. }\end{array}$ & INRIX [145] \\
\hline Cost Considered & $\begin{array}{l}\text { Description of Approach for Bicycles, } \\
\text { Pedelecs, and e-Scooter }\end{array}$ & Main Source(s) \\
\hline Bicycle, Pedelecs, E-pedelecs & $\begin{array}{l}\text { TCO information for bicycles from } \\
\text { different sources }\end{array}$ & $\begin{array}{c}\text { Fahrrad.de [146], VSF [147], ZIV } \\
\text { [148,149], Fahrradblog [150], } \\
\text { Schwalbe [151], [86], GHOST [152] }\end{array}$ \\
\hline E-scooter & $\begin{array}{l}\text { TCO information for bicycles from } \\
\text { different sources }\end{array}$ & $\begin{array}{c}\text { BGBI [153,154], IEEE [155], Journals } \\
\text { [156], BCG [157] }\end{array}$ \\
\hline
\end{tabular}

Table A4. Price structure for various service-based transport modes in Munich.

\begin{tabular}{|c|c|c|c|c|c|c|}
\hline Transport Mode & Vehicle Type & Min. Price & Base Price & Price per Min & Price per Hour & Price per km \\
\hline Car sharing $\left(\mathrm{FF}^{1)}\right)$ & Mini car & $\mathrm{n} / \mathrm{a}$ & $\mathrm{n} / \mathrm{a}$ & $0.19 € / \mathrm{min}$ & $\mathrm{n} / \mathrm{a}$ & $\mathrm{n} / \mathrm{a}$ \\
\hline Car sharing $\left(\mathrm{FF}^{1)}\right)$ & Small car & $\mathrm{n} / \mathrm{a}$ & $\mathrm{n} / \mathrm{a}$ & $0.28 € / \mathrm{min}$ & $\mathrm{n} / \mathrm{a}$ & $\mathrm{n} / \mathrm{a}$ \\
\hline Car sharing $\left(\mathrm{FF}^{1)}\right)$ & Medium car & $\mathrm{n} / \mathrm{a}$ & $\mathrm{n} / \mathrm{a}$ & $0.31 € / \mathrm{min}$ & $\mathrm{n} / \mathrm{a}$ & $\mathrm{n} / \mathrm{a}$ \\
\hline Car sharing ( $\mathrm{SB}^{2)}$ ) & Mini car & $\mathrm{n} / \mathrm{a}$ & $\mathrm{n} / \mathrm{a}$ & $\mathrm{n} / \mathrm{a}$ & $2.30 € / \mathrm{h}$ & $0.23 € / \mathrm{km}$ \\
\hline Car sharing $\left(\mathrm{SB}^{2)}\right)$ & Small car & $\mathrm{n} / \mathrm{a}$ & $\mathrm{n} / \mathrm{a}$ & $\mathrm{n} / \mathrm{a}$ & $2.65 € / h$ & $0.27 € / \mathrm{km}$ \\
\hline Car sharing $\left(\mathrm{SB}^{2)}\right)$ & Medium car & $\mathrm{n} / \mathrm{a}$ & $\mathrm{n} / \mathrm{a}$ & $\mathrm{n} / \mathrm{a}$ & $3.00 € / \mathrm{h}$ & $0.3 € / \mathrm{km}$ \\
\hline Bike sharing & Bicycle & $\mathrm{n} / \mathrm{a}$ & $\mathrm{n} / \mathrm{a}$ & $0.08 € / \mathrm{min}$ & $\mathrm{n} / \mathrm{a}$ & $\mathrm{n} / \mathrm{a}$ \\
\hline E-Scooter sharing & E-Scooter & $\mathrm{n} / \mathrm{a}$ & $1.00 €$ & $0.19 € / \mathrm{min}$ & $\mathrm{n} / \mathrm{a}$ & $\mathrm{n} / \mathrm{a}$ \\
\hline Scooter sharing & Motorized Scooter & $\mathrm{n} / \mathrm{a}$ & $\mathrm{n} / \mathrm{a}$ & $0.27 € / \mathrm{min}$ & $\mathrm{n} / \mathrm{a}$ & $\mathrm{n} / \mathrm{a}$ \\
\hline
\end{tabular}


Table A4. Cont.

\begin{tabular}{|c|c|c|c|c|c|c|}
\hline Transport Mode & Vehicle Type & Min. Price & Base Price & Price per Min & Price per Hour & Price per km \\
\hline Ride-hailing & Medium/large car & $5.00 €$ & $2.00 €$ & $0.31 € / \mathrm{min}$ & $\mathrm{n} / \mathrm{a}$ & $0.90 € / \mathrm{km}$ \\
\hline Ride-hailing & Medium/large car & $5.00 €$ & $2.00 €$ & $0.31 € / \mathrm{min}$ & $\mathrm{n} / \mathrm{a}$ & $0.90 € / \mathrm{km}$ \\
\hline Ride-hailing & Executive car & $9.00 €$ & $6.00 €$ & $0.50 € / \mathrm{min}$ & $\mathrm{n} / \mathrm{a}$ & $1.50 € / \mathrm{km}$ \\
\hline Ride-hailing & Van & $9.00 €$ & $6.00 €$ & $0.50 € / \mathrm{min}$ & $\mathrm{n} / \mathrm{a}$ & $1.50 € / \mathrm{km}$ \\
\hline Taxi $^{3}$ & Executive car & $\mathrm{n} / \mathrm{a}$ & $3.70 €$ & $\mathrm{n} / \mathrm{a}$ & $\mathrm{n} / \mathrm{a}$ & $1.70-2.00 € / \mathrm{km}$ \\
\hline Transport Mode & \multicolumn{2}{|c|}{ Ticket Type } & \multicolumn{2}{|c|}{ Price per ride in $€$ * } & \multicolumn{2}{|c|}{ Price per year in $€ *$} \\
\hline Subway/Streetcar/Bus & \multicolumn{2}{|c|}{ Single Ticket } & \multicolumn{2}{|c|}{$3.39 €$} & \multicolumn{2}{|c|}{$2471.20 €$} \\
\hline Subway/Streetcar/Bus & \multicolumn{2}{|c|}{ Daily Ticket } & \multicolumn{2}{|c|}{$4.01 €$} & \multicolumn{2}{|c|}{$2920.50 €$} \\
\hline Subway/Streetcar/Bus & \multicolumn{2}{|c|}{ Weekly Ticket } & \multicolumn{2}{|c|}{$1.31 €$} & \multicolumn{2}{|c|}{$914.70 €$} \\
\hline Subway/Streetcar/Bus & \multicolumn{2}{|c|}{ Monthly Ticket } & \multicolumn{2}{|c|}{$0.97 €$} & \multicolumn{2}{|c|}{$681.40 €$} \\
\hline Subway/Streetcar/Bus & \multicolumn{2}{|c|}{ Annual Ticket } & \multicolumn{2}{|c|}{$0.77 €$} & \multicolumn{2}{|c|}{$536.90 €$} \\
\hline Subway/Streetcar/Bus & \multicolumn{2}{|c|}{ Stripe Ticket } & \multicolumn{2}{|c|}{$1.65 €$} & \multicolumn{2}{|c|}{$1153.20 €$} \\
\hline Subway/Streetcar/Bus & \multicolumn{2}{|c|}{ Semester Ticket } & \multicolumn{2}{|c|}{$0.58 €$} & \multicolumn{2}{|c|}{$402.60 €$} \\
\hline
\end{tabular}

${ }^{1}$ Free-floating; ${ }^{2}$ Station-based; ${ }^{3}$ For taxies, a further $0.50 € / \mathrm{min}$ must be added to account for waiting time. Sources: Car-sharing [158-161], Bike-sharing [162], E-scooter-sharing [163-165], Scooter sharing [166], Ride-hailing [167,168], Taxi [169]. * for exemplary rides within Zone M; 2 rides per day; 7 days a week, 50 weeks a year using service. Sources: Public Transport $[75,170,171]$.

\section{References}

1. Nicoletti, L.; Bronner, M.; Danquah, B.; Koch, A.; Konig, A.; Krapf, S.; Pathak, A.; Schockenhoff, F.; Sethuraman, G.; Wolff, S.; et al Review of trends and potentials in the vehicle concept development process. In Proceedings of the 2020 Fifteenth International Conference on Ecological Vehicles and Renewable Energies (EVER), Monte-Carlo, Monaco, 10-12 September 2020; pp. 1-5, ISBN 978-1-7281-5641-5.

2. Trommer, S.; Kolarova, V.; Fraedrich, E.; Kröger, L.; Kickhöfer, B.; Kuhnimhof, T.; Lenz, B.; Phleps, P. Autonomous Driving. The Impact of Vehicle Automation on Mobility Behavior; Institute for Mobility Research: Munich, Germany, 2016. Available online: https://www.researchgate.net/publication/312374304_Autonomous_Driving_-_The_Impact_of_Vehicle_Automation_ on_Mobility_Behaviour (accessed on 20 December 2020).

3. Nicoletti, L.; Romano, A.; König, A.; Schockenhoff, F.; Lienkamp, M. Parametric Modeling of Mass and Volume Effects for Battery Electric Vehicles, with Focus on the Wheel Components. WEVJ 2020, 11, 63. [CrossRef]

4. Kochhan, R.; Fuchs, S.; Reuter, B.; Burda, P.; Matz, S.; Lienkamp, M. An Overview of Costs for Vehicle Components, Fuels and Greenhouse Gas Emissions. Available online: https:/ /www.researchgate.net/publication/260339436_An_Overview_of_Costs_ for_Vehicle_Components_Fuels_and_Greenhouse_Gas_Emissions (accessed on 15 December 2020).

5. Fries, M.; Kerler, M.; Rohr, S.; Schickram, S. An Overview of Costs for Vehicle Components, Fuels, Greenhouse Gas Emissions and Total Cost of Ownership: Update 2017. Available online: https://www.researchgate.net/publication/319136996_An_Overview_ of_Costs_for_Vehicle_Components_Fuels_Greenhouse_Gas_Emissions_and_Total_Cost_of_Ownership_-_Update_2017 (accessed on 28 October 2020).

6. OFX. Yearly Average Rates. Available online: https://www.ofx.com/en-au/forex-news/historical-exchange-rates/yearlyaverage-rates / (accessed on 28 October 2020).

7. Triami Media BV. Historic Harmonised Inflation Europe-HICP Inflation. Available online: https://www.inflation.eu/en/ inflation-rates/europe/historic-inflation/hicp-inflation-europe.aspx (accessed on 28 October 2020).

8. Miller, J. Electric Car Costs to Remain Higher than Traditional Engines. Available online: https://www.ft.com/content/a7e58ce7 -4fab-424a-b1fa-f833ce948cb7 (accessed on 8 December 2020).

9. Ruffo, G. EVs Are Still 45\% More Expensive to Make Than Combustion-Engined Cars. Available online: https://insideevs.com/ news /444542/evs-45-percent-more-expensive-make-ice/ (accessed on 8 December 2020).

10. Kampker, A.; Vallée, D.; Schnettler, A. Elektromobilität; Springer: Berlin/Heidelberg, Germany, 2018; ISBN 978-3-662-53136-5.

11. Schmuch, R.; Wagner, R.; Hörpel, G.; Placke, T.; Winter, M. Performance and cost of materials for lithium-based rechargeable automotive batteries. Nat. Energy 2018, 3, 267-278. [CrossRef]

12. Matz, S.; Fuchs, J.; Burda, P.; Horlbeck, L.; Eckl, R.; Lienkamp, M. Beschreibung der Modellierungsart Sowie der Modellierungsparameter von Elektrofahrzeugen in der Konzeptphase. Available online: https://www.researchgate.net/publication/261174335_ Beschreibung_der_Modellierungsart_sowie_der_Modellierungsparameter_von_Elektrofahrzeugen_in_der_Konzeptphase (accessed on 28 October 2020).

13. Scrosati, B.; Garche, J.; Tillmetz, V. (Eds.) Advances in Battery Technologies for Electric Vehicles, 1st ed.; Woodhead Publishing: Cambridge, UK, 2015; ISBN 9781782423980.

14. Blomgren, G.E. The Development and Future of Lithium Ion Batteries. J. Electrochem. Soc. 2017, 164, A5019-A5025. [CrossRef]

15. Anderman, M. Extract from the xEV Insider Report. April 2019 Edition. Available online: https://totalbatteryconsulting.com/ industry-reports/xEV-report/Extract-from-the-xEV-Industry-Report.pdf (accessed on 8 October 2020). 
16. Fink, H. Li-ion batteries for automotive applications-Quo vadis. In Internationales Stuttgarter Symposium; Bargende, M., Reuss, H.-C., Wiedemann, J., Eds.; Springer Fachmedien: Wiesbaden, Germany, 2016; pp. 69-81. ISBN 978-3-658-13254-5.

17. Fuchs, S. Verfahren zur Parameterbasierten Gewichtsabschätzung neuer Fahrzeugkonzepte. Ph.D. Thesis, Institute of Automotive Technology, Technical University of Munich, Munich, Germany, 2014.

18. Placke, T.; Kloepsch, R.; Dühnen, S.; Winter, M. Lithium ion, lithium metal, and alternative rechargeable battery technologies: The odyssey for high energy density. J. Solid State Electrochem. 2017, 21, 1939-1964. [CrossRef]

19. Thielmann, A.; Neef, C.; Hettesheimer, T.; Döscher, H.; Wietschel, M.; Tübke, J. Energiespeicher-Roadmap (Update 2017). Hochenergie-Batterien 2030+ und Perspektiven Zukünftiger Batterietechnologien. 2017. Available online: https://www. isi.fraunhofer.de/content/dam/isi/dokumente/cct/lib/Energiespeicher-Roadmap-Dezember-2017.pdf (accessed on 1 October 2020).

20. Volkswagen AG. Powerful and Scalable: The New ID. Battery System. Available online: https://www.volkswagenag.com/en/ news / stories / 2018/10/powerful-and-scalable-the-new-id-battery-system.html (accessed on 29 June 2020).

21. Hagen, M.; Hanselmann, D.; Ahlbrecht, K.; Maça, R.; Gerber, D.; Tübke, J. Lithium-Sulfur Cells: The Gap between the State-ofthe-Art and the Requirements for High Energy Battery Cells. Adv. Energy Mater. 2015, 5, 1-11. [CrossRef]

22. Frieske, B.; van der Adel, B.; Schwarz-Kocher, M.; Stieler, S.; Schnabel, A.; Tözün, R. Strukturstudie BWe Mobil 2019: Transformation durch Elektromobilität und Perspektiven der Digitalisierung. Available online: https://www.e-mobilbw.de/service/ meldungen-detail/strukturstudie-bwe-mobil-2019 (accessed on 26 October 2020).

23. Nicoletti, L.; Mirti, S.; Schockenhoff, F.; König, A.; Lienkamp, M. Derivation of Geometrical Interdependencies between the Passenger Compartment and the Traction Battery Using Dimensional Chains. WEVJ 2020, 11, 39. [CrossRef]

24. Knecht, J.; Stegmaier, G.; Hebermehl, G. Tesla Battery Day 2020. Available online: https://www.auto-motor-und-sport.de/techzukunft/tesla-battery-day-neue-zellen-kosten-halbiert/ (accessed on 28 October 2020).

25. Bos, C. Tesla's New Structural Battery Pack-It's Not Cell-to-Pack, It's Cell-to-Body. CleanTechnica [Online]. 11 October 2020. Available online: https:/ / cleantechnica.com/2020/10/10/teslas-new-structural-battery-pack-its-not-cell-to-pack-its-cell-tobody / (accessed on 25 October 2020).

26. Grunditz, E.A.; Thiringer, T. Performance Analysis of Current BEVs Based on a Comprehensive Review of Specifications. IEEE Trans. Transp. Electrific. 2016, 2, 270-289. [CrossRef]

27. Fuchss, S.; Michaelides, A.; Stocks, O.; Devenport, R. Das Antriebssystem des neuen Jaguar I-Pace. MTZ Motortech. Z. 2019, 80, 20-27. [CrossRef]

28. Grebe, U.D.; Nitz, L.T. Voltec-Das Antriebssystem für Chevrolet Volt und Opel Ampera. MTZ Motortech. Z. 2011, 72, 342-351. [CrossRef]

29. ADAC. Autodatenbank. Available online: https://www.adac.de/infotestrat/autodatenbank/autokatalog/default.aspx (accessed on 26 November 2019).

30. Busche, I. Ein Beitrag zur Optimierten Konzeptauslegung von Fahrzeugen im Bereich der Elektromobilität. Ph.D. Thesis, University of Magdeburg, Magdeburg, Germany, 2014.

31. Zubi, G.; Dufo-López, R.; Carvalho, M.; Pasaoglu, G. The lithium-ion battery: State of the art and future perspectives. Reneww. Sustain. Energy Rev. 2018, 89, 292-308. [CrossRef]

32. Hoekstra, A. The Underestimated Potential of Battery Electric Vehicles to Reduce Emissions. Joule 2019, 3, 1412-1414. [CrossRef]

33. Nykvist, B.; Nilsson, M. Rapidly falling costs of battery packs for electric vehicles. Nat. Clim. Chang. 2015, 5, 329-332. [CrossRef]

34. Philippot, M.; Alvarez, G.; Ayerbe, E.; van Mierlo, J.; Messagie, M. Eco-Efficiency of a Lithium-Ion Battery for Electric Vehicles: Influence of Manufacturing Country and Commodity Prices on GHG Emissions and Costs. Batteries 2019, 5, 23. [CrossRef]

35. Cano, Z.P.; Banham, D.; Ye, S.; Hintennach, A.; Lu, J.; Fowler, M.; Chen, Z. Batteries and fuel cells for emerging electric vehicle markets. Nat. Energy 2018, 3, 279-289. [CrossRef]

36. Nationale Plattform Zukunft der Mobilität. 1. Kurzbericht der AG 2-Elektromobilität. Brennstoffzelle. Alternative KraftstoffeEinsatzmöglichkeiten aus Technologischer Sicht (1st Short Report of AG 2-Electromobility. Fuel Cell. Alternative Fuel Applications from a Technological Perspective.). 2019. Available online: https:/ /www.plattform-zukunft-mobilitaet.de/wpcontent/uploads/2019/11/NPM-AG-2-Elektromobilit\%C3\%A4t-Brennstoffzelle-Alternative-Kraftstoffe-Einsatzm\%C3\%B6 glichkeiten-aus-technologischer-Sicht.pdf (accessed on 8 April 2020).

37. Wentker, M.; Greenwood, M.; Leker, J. A Bottom-Up Approach to Lithium-Ion Battery Cost Modeling with a Focus on Cathode Active Materials. Energies 2019, 12, 504. [CrossRef]

38. Hettesheimer, T.; Thielmann, A.; Neef, C.; Möller, K.-C.; Wolter, M.; Lorentz, V.; Gepp, M.; Wenger, M.; Prill, T.; Zausch, J.; et al. Entwicklungsperspektiven für Zellformate von Lithium-Ionen-Batterien in der Elektromobilität (Development Prospects for Cell Formats of Lithium-ion Batteries in Electromobility). 2017. Available online: https://www.batterien.fraunhofer.de/content/ dam/batterien/de/documents/Allianz_Batterie_Zellformate_Studie.pdf (accessed on 15 December 2020).

39. Kerler, M. Eine Methode zur Bestimmung der Optimalen Zellgröße für Elektrofahrzeuge. Ph.D. Thesis, Technische Universität München, München, Germany, 2018.

40. Nelson, P.A.; Gallagher, K.G.; Bloom, I.; Dees, D.W. Modeling the Performance and Cost of Lithium-Ion Batteries for Electric-Drive Vehicles. 2011. Available online: https:/ / publications.anl.gov/anlpubs/2011/10/71302.pdf (accessed on 5 November 2020). 
41. Romare, M.; Dahllöf, L. The Life Cycle Energy Consumption and Greenhouse Gas Emissions from Lithium-Ion Batteries. 2017. Available online: http:/ / www.energimyndigheten.se/globalassets/forskning--innovation/transporter/c243-the-life-cycleenergy-consumption-and-co2-emissions-from-lithium-ion-batteries-.pdf (accessed on 15 December 2020).

42. Emilsson, E.; Dahllöf, L. Lithium-Ion Vehicle Battery Production; IVL Swedish Environmental Research Institute: Stockholm, Sweden, 2019; ISBN 978-91-7883-112-8.

43. Dai, Q.; Kelly, J.C.; Gaines, L.; Wang, M. Life Cycle Analysis of Lithium-Ion Batteries for Automotive Applications. Batteries 2019, 5, 48. [CrossRef]

44. Kelly, J.C.; Dai, Q.; Wang, M. Globally regional life cycle analysis of automotive lithium-ion nickel manganese cobalt batteries. Mitig. Adapt. Strateg. Glob. Change 2020, 25, 371-396. [CrossRef]

45. Schweigert, D.; Gerlach, M.E.; Hoffmann, A.; Morhard, B.; Tripps, A.; Lohner, T.; Otto, M.; Ponick, B.; Stahl, K. On the Impact of Maximum Speed on the Power Density of Electromechanical Powertrains. Vehicles 2020, 2, 365-397. [CrossRef]

46. Nicoletti, L.; Mayer, S.; Brönner, M.; Schockenhoff, F.; Lienkamp, M. Design Parameters for the Early Development Phase of Battery Electric Vehicles. WEVJ 2020, 11, 47. [CrossRef]

47. Angerer, C.R. Antriebskonzept-Optimierung für Batterieelektrische Allradfahrzeuge. Ph.D. Thesis, Institute of Automotive Technology, Technical University of Munich, Verlag Dr. Hut, Munich, Germany, 2020.

48. Nemeth, T.; Bubert, A.; Becker, J.N.; de Doncker, R.W.; Sauer, D.U. A Simulation Platform for Optimization of Electric Vehicles with Modular Drivetrain Topologies. IEEE Trans. Transp. Electrific. 2018, 4, 888-900. [CrossRef]

49. Kasper, R.; Schünemann, M. 5. Elektrische Fahrantriebe Topologien Und Wirkungsgrad. MTZ Motortech. Z. 2012, 73, 802-807. [CrossRef]

50. Nicoletti, L.; Ostermann, F.; Heinrich, M.; Stauber, A.; Lin, X.; Lienkamp, M. Topology analysis of electric vehicles, with a focus on the traction battery. Forsch. Ing. 2020. [CrossRef]

51. Rimac Automobili C_Two Hypercar. Rimac Automobili C_Two Hypercar-A Car Alive with Technology. Available online: https:/ / www.rimac-automobili.com/en/hypercars/c_two/ (accessed on 26 October 2020).

52. Porsche Newsroom. Der Antrieb: Performance pur. Available online: https://newsroom.porsche.com/de/produkte/taycan/ antrieb-18543.html (accessed on 26 October 2020).

53. Naunheimer, H.; Bertsche, B.; Ryborz, J.; Novak, W.; Fietkau, P. Fahrzeuggetriebe. Grundlagen, Auswahl, Auslegung und Konstruktion, 3rd ed.; Auflage 2019; Springer: Berlin/Heidelberg, Germany, 2019; ISBN 978-3-662-58883-3.

54. Dominguez Olavarria, G.; Marquez-Fernandez, F.J.; Fyhr, P.; Reinap, A.; Andersson, M.; Alaküla, M. Scalable performance, efficiency and thermal models for electric drive components used in powertrain simulation and optimization. In Proceedings of the 2017 IEEE Transportation Electrification Conference and Expo (ITEC), Chicago, IL, USA, 22-24 June 2017; pp. 644-649, ISBN 978-1-5090-3953-1.

55. Pesce, T. Ein Werkzeug zur Bestimmung von Individuell Optimalen Antriebssträngen für Elektrofahrzeuge. Ph.D. Thesis, Technische Universität München, München, Germany, 2014.

56. Ried, M. Lösungsraumanalyse für Plug-In-Hybridfahrzeuge Hinsichtlich Wirtschaftlichkeit und Bauraumkonzept. Ph.D. Thesis, Universität Duisburg-Essen, Lehrstuhl für Mechatronik, Duisburg-Essen, Germany, 2016.

57. Chang, F. Improving the Partial Load Efficiency of Electric Powertrains by Silicon MOSFET Multilevel Inverters. Ph.D. Thesis, Technical University of Munich, Munich, Germany, 2019.

58. Wacker, P.; Wheldon, L.; Sperlich, M.; Adermann, J.; Lienkamp, M. Influence of active battery switching on the drivetrain efficiency of electric vehicles. In Proceedings of the 2017 IEEE Transportation Electrification Conference and Expo (ITEC), Chicago, IL, USA, 22-24 June 2017; pp. 33-38, ISBN 978-1-5090-3953-1.

59. Chang, F.; Ilina, O.; Hegazi, O.; Voss, L.; Lienkamp, M. Adopting MOSFET multilevel inverters to improve the partial load efficiency of electric vehicles. In Proceedings of the 2017 19th European Conference on Power Electronics and Applications (EPE'17 ECCE Europe), Warsaw, Poland, 11-14 September 2017; pp. 1-13.

60. Brooker, A.; Gonder, J.; Wang, L.; Wood, E.; Lopp, S.; Ramroth, L. FASTSim: A Model to Estimate Vehicle Efficiency, Cost and Performance. In Proceedings of the SAE 2015 World Congress \& Exhibition, Detroit, MI, USA, 21-23 April 2015.

61. Del Duce, A.; Gauch, M.; Althaus, H.-J. Electric passenger car transport and passenger car life cycle inventories in ecoinvent version 3. Int. J. Life Cycle Assess. 2016, 21, 1314-1326. [CrossRef]

62. WirtschaftsWoche. Zusammensetzung des Preises Eines Neuwagens in Deutschland. Available online: https://de.statista. com/statistik/daten/studie/387632/umfrage/zusammensetzung-des-neuwagenpreises-in-deutschland/ (accessed on 9 December 2020).

63. Institute of Automotive Technology (FTM). Figures Based on Expert Discussions; Institute Automotive Technology (FTM): Technical University of Munich: Munich, Germany, 2020.

64. Mosquet, X.; Dauner, T.; Lang, N.; Russmann, M.; Mei-Pochtler, A.; Agrawal, R.; Schmieg, F. Revolution in the Driver's Seat: The Road to Autonomous Vehicles; The Boston Consulting Group: Boston, MA, USA, 2015.

65. Priddle, A.; Woodyard, C. Google Discloses Costs of Ist Driverless Car Tests. Available online: http:/ / content.usatoday.com/ communities/driveon/post/2012/06/google-discloses-costs-of-its-driverless-car-tests/1 (accessed on 27 October 2020).

66. Krok, A. Velodyne Just Made Self-Driving Cars a Bit Less Expensive. Available online: https://www.cnet.com/roadshow/news/ velodyne-just-made-self-driving-cars-a-bit-less-expensive-hopefully / (accessed on 27 October 2020). 
67. Velodyne Lidar. Velodyne Slashes the Price in Half of Its Most Popular LiDAR Sensor. Available online: https:/ / velodynelidar. $\mathrm{com} /$ press-release/velodyne-slashes-the-price-in-half-of-its-most-popular-lidar-sensor/ (accessed on 27 October 2020).

68. Ouster, Inc. Ouster OS1 Mid-Range LiDAR Sensor. Available online: https:/ / ouster.com/products/os1-lidar-sensor/ (accessed on 27 October 2020).

69. Deyle, T. Velodyne HDL-32E: A New High-End Laser Rangefinder. Available online: http:/ www.hizook.com/blog/2010/08/24 / velodyne-hdl-32e-new-high-end-laser-rangefinder (accessed on 27 October 2020).

70. Pacala, A. The ES2: The First True Solid-State High-Performance Digital Lidar. Available online: https://ouster.com/blog/thees2-the-first-true-solid-state-high-performance-digital-lidar/ (accessed on 27 October 2020).

71. General Laser. Mid-Range Lidar Sensors-Ouster OS1. Available online: https://www.general-laser.at/shop-de/lidar-de/ousteros1-de (accessed on 27 October 2020).

72. Woodside Capital Partners WCP. The Automotive LiDAR Market. Available online: http://www.woodsidecap.com/wp-content/ uploads/2018/04/Yole_WCP-LiDAR-Report_April-2018-FINAL.pdf (accessed on 10 November 2020).

73. Nvidia. Jetson AGX Xavier. Available online: https://www.nvidia.com/de-de/autonomous-machines/embedded-systems/ jetson-agX-xavier/ (accessed on 30 October 2020).

74. SYSTEMPlus Consulting. A Tesla Model 3 Tear-Down after a Hardware Retrofit. Available online: https://www.eetimes.com/atesla-model-3-tear-down-after-a-hardware-retrofit/4/ (accessed on 30 October 2020).

75. MVV. Der MVV in Zahlen. Available online: https://www.mvv-muenchen.de/mvv-und-service/der-verbund/mvv-in-zahlen/ index.html (accessed on 15 June 2020).

76. Bösch, P.M.; Becker, F.; Becker, H.; Axhausen, K.W. Cost-based analysis of autonomous vehicle services. Transp. Policy 2018. [CrossRef]

77. Arellano, J.F.; Fang, K. Sunday Drivers, or Too Fast and Too Furious? Transp. Find. 2019. [CrossRef]

78. BFS; ARE. Swiss Federal Statistical Office (BFS) and Swiss Federal Office for Spatial Development (ARE)-Mobilität in der Schweiz-Ergebnisse des Mikrozensus Mobilität und Verkehr 2010. Available online: https://www.bfs.admin.ch/bfs/en/home/ statistics/catalogues-databases / publications.assetdetail.348719.html (accessed on 18 December 2020).

79. Hardt, C.; Bogenberger, K. Usability of escooters in urban environments-a pilot study. In Proceedings of the 2017 IEEE Intelligent Vehicles Symposium (IV), Los Angeles, CA, USA, 11-17 June 2017. [CrossRef]

80. INRIX. INRIX Global Traffic Scorecard. Available online: https://inrix.com/scorecard/ (accessed on 18 December 2020).

81. INRIX. Manchester Revealed as UK City with the Most Potential for Shared Bikes and E-Scooters. Available online: https: //inrix.com/press-releases/micromobility-study-uk-2019/ (accessed on 30 September 2020).

82. Jäger, B.; Wittmann, M.; Lienkamp, M. Analyzing and modeling a City's spatiotemporal taxi supply and demand: A case study for Munich. J. Traffic Logist. Eng. 2016, 4. [CrossRef]

83. Jiao, J.; Bai, S. Understanding the Shared E-scooter Travels in Austin, TX. ISPRS Int. J. Geo-Inf. 2020, 9, 135. [CrossRef]

84. Knoblauch, R.L.; Pietrucha, M.T.; Nitzburg, M. Field Studies of Pedestrian Walking Speed and Start-Up Time. Transp. Res. Rec. 1996, 1538, 27-38. [CrossRef]

85. Schleinitz, K.; Petzoldt, T.; Franke-Bartholdt, L.; Krems, J.; Gehlert, T. The German Naturalistic Cycling Study-Comparing cycling speed of riders of different e-bikes and conventional bicycles. Saf. Sci. 2017, 92, 290-297. [CrossRef]

86. Wachotsch, U.; Kolodziej, A.; Specht, B.; Kohlmeyer, R.; Petrikowski, F. E-Rad Macht Mobil: Potenziale von Pedelecs und Deren Umweltwirkung. Available online: https://www.umweltbundesamt.de/sites/default/files/medien/378/publikationen/hgp_erad_macht_mobil_-_pelelecs_4.pdf (accessed on 18 December 2020).

87. Zou, Z.; Younes, H.; Erdoğan, S.; Wu, J. Exploratory Analysis of Real-Time E-Scooter Trip Data in Washington, DC. Transp. Res. Rec. 2020, 0361198120919760. [CrossRef]

88. Sperling, D. Three Revolutions: Steering Automated, Shared, and Electric Vehicles to a Better Future; Island Press: Washington, DC, USA, 2018; ISBN 9781610919050.

89. Compostella, J.; Fulton, L.M.; de Kleine, R.; Kim, H.C.; Wallington, T.J. Near-(2020) and long-term (2030-2035) costs of automated, electrified, and shared mobility in the United States. Transp. Policy 2020, 85, 54-66. [CrossRef]

90. Ongel, A.; Loewer, E.; Roemer, F.; Sethuraman, G.; Chang, F.; Lienkamp, M. Economic assessment of autonomous electric microtransit vehicles. Sustainability 2019, 11, 648. [CrossRef]

91. Lim, L.; Tawfik, A.M. Estimating future travel costs for autonomous vehicles (AVs) and shared autonomous vehicles (SAVs). In Proceedings of the 2018 21st International Conference on Intelligent Transportation Systems (ITSC), Maui, HI, USA, 4-7 November 2018; pp. 1702-1707, ISBN 978-1-7281-0321-1.

92. Dandl, F.; Bogenberger, K. Comparing Future Autonomous Electric Taxis with an Existing Free-Floating Carsharing System. IEEE Trans. Intell. Transp. Syst. 2019, 20, 2037-2047. [CrossRef]

93. European Comission. DG MOVE-Handbook on the External Costs of Transport; European Comission: Brussels, Belgium, 2019; ISBN 978-92-79-96917-1.

94. Bieler, C.; Sutter, D. Externe Kosten des Verkehrs in Deutschland. Straßen-, Schienen-, Luft-und Binnenschiffverkehr. 2017. Available online: https:/ / www.allianz-pro-schiene.de/wp-content/uploads/2019/08/190826-infras-studie-externe-kosten-verkehr.pdf (accessed on 20 December 2020).

95. Gössling, S.; Choi, A.; Dekker, K.; Metzler, D. The Social Cost of Automobility, Cycling and Walking in the European Union. Ecol. Econ. 2019, 158. [CrossRef] 
96. Jochem, P.; Doll, C.; Fichtner, W. External costs of electric vehicles. Transp. Res. Part D Transp. Environ. 2016, 42, 60-76. [CrossRef]

97. Weiss, C.; Mallig, N.; Heilig, M.; Schneidereit, T.; Franke, T.; Vortisch, P. How much range is required? A model based analysis of potential battery electric vehicle usage. In Proceedings of the Transportation Research Board 95th Annual Meeting, Washington DC, USA, 10-14 January 2016.

98. Trantow, M.; Franke, T.; Günther, M.; Krems, J.F.; Rauh, N. Range comfort zone of electric vehicle users-concept and assessment. IET Intell. Transp. Syst. 2015, 9, 740-745. [CrossRef]

99. Machiels, N.; Leemput, N.; Geth, F.; van Roy, J.; Buscher, J.; Driesen, J. Design Criteria for Electric Vehicle Fast Charge Infrastructure Based on Flemish Mobility Behavior. IEEE Trans. Smart Grid 2014, 5, 320-327. [CrossRef]

100. Pfriem, M. Analyse der Realnutzung von Elektrofahrzeugen in Kommerziellen Flotten zur Definition Einer Bedarfsgerechten Fahrzeugauslegung. Ph.D. Thesis, Karlsruher Institut für Technologie, Karlsruhe, Germany, 2015.

101. Corchero, C.; Gonzalez-Villafranca, S.; Sanmarti, M. European electric vehicle fleet: Driving and charging data analysis. In Proceedings of the 2014 IEEE International Electric Vehicle Conference (IEVC), Florence, Italy, 17-19 December 2014; pp. 1-6. [CrossRef]

102. Krug, S.; Krey, O.; Ohm, B.; Weider, M.; Ziem-Milojevic, S.; Braune, O. Elektromobilität in der Praxis. Zweiter Ergebnisbericht des Zentralen Datenmonitorings des Förderprogramms Elektromobilität vor Ort. 2020. Available online: https:/ /www.now-gmbh. de/wp-content/uploads/2020/09/now_elektromobilitaet-in-der-praxis-zdm.pdf (accessed on 15 November 2020).

103. Schuster, A. Batterie- bzw. Wasserstoffspeicher bei elektrischen Fahrzeugen. Master's Thesis, Technical University of Wien, Wien, Austria, 2008.

104. Fieltsch, P.; Flämig, H.; Rosenberger, K. Analysis of charging behavior when using battery electric vehicles in commercial transport. Transp. Res. Procedia 2020, 46, 181-188. [CrossRef]

105. Betz, J.; Hann, M.; Jäger, B.; Lienkamp, M. Evaluation of the potential of integrating battery electric vehicles into commercial companies on the basis of fleet test data. In Proceedings of the 2017 IEEE 85th Vehicular Technology Conference (VTC Spring), Sydney, NSW, Australia, 4-7 June 2017; IEEE: Piscataway, NJ, USA, 2017; pp. 1-7, ISBN 978-1-5090-5932-4.

106. Waclaw, A.; Aloise, T.; Lienkamp, M. Charging infrastructure design for commercial company sites with battery electric vehicles: A case study of a Bavarian Bakery: Article submitted for publication. In Proceedings of the 2020 Fifteenth International Conference on Ecological Vehicles and Renewable Energies (EVER), Monte-Carlo, Monaco, 28-30 May 2020. [CrossRef]

107. European Parliament. Directive (EU) 96/53/EC of 25 July 1996 Laying down fo Rcertain Road Vehicles Circulating within the Community the Maximum Authorized Dimensions in National and International Traffic and the Maximum Authorized Weights Ininternational Traffic; Directive (EU) 96/53/EC; European Parliament: Brussels, Belgium, 1996. Available online: https:/ / eur-lex.europa.eu/legalcontent/EN/TXT/?uri=CELEX\%3A31996L0053 (accessed on 15 December 2020).

108. Márquez-Fernández, F.J.; Domingues, G.; Lindgren, L.; Alaküla, M. Electric Roads: The importance of sharing the infrastructure among different vehicle types. In Proceedings of the IEEE Transportation Electrification Conference and Expo, Asia-Pacific (ITEC Asia-Pacific), Harbin, China, 7-10 August 2017. [CrossRef]

109. Wolff, S.; Fries, M.; Lienkamp, M. Technoecological analysis of energy carriers for long-haul transportation. J. Ind. Ecol. 2019, 49, 6402. [CrossRef]

110. Bateman, D.; Leal, D.; Reeves, S.; Emre, M.; Stark, L.; Ognissanto, F.; Myers, R.; Lamb, M. Electric Road Systems: A Solution for the Future? 2018. Available online: https:/ / www.piarc.org/en/order-library/29690-en-Electric\%20road\%20systems:\%20a\%20 solution\%20for\%20the\%20future (accessed on 15 October 2020).

111. Moultak, M.; Lutsey, N.; Hall, D. Transitioning to Zero-Emission Heavy-Duty Freight Vehicles. 2017. Available online: https: / / theicct.org/publications/transitioning-zero-emission-heavy-duty-freight-vehicles (accessed on 2 February 2021).

112. Gesetz für den Ausbau Erneuerbarer Energien (Erneuerbare-Energien-Gesetz-EEG 2017) (Act for the Expansion of Renewable Energies [Renewable Energies Act-EEG 2017]). IdF d. Art. 1 Nr. 1 G v. 13.10.2016. 2014. Available online: https://www.gesetzeim-internet.de/eeg_2014/EEG_2017.pdf (accessed on 10 January 2021).

113. Federal Minister for Environment, Nature Conservation and Nuclear Safety. Klimaschutzprogramm 2030 der Bundesregierung zur Umsetzung des Klimaschutzplans 2050 (Climate Protection Program 2030 of the Federal Government to implement the Climate Protection Plan 2050). 2019. Available online: https://www.bundesregierung.de/resource/blob/975226/1679914/e01d6 bd855f09bf05cf7498e06d0a3ff / 2019-10-09-klima-massnahmen-data.pdf (accessed on 15 December 2020).

114. Schmidt, P.R.; Zittel, W.; Weindorf, W.; Raksha, T. Renewables in Transport 2050. Empowering a Sustainable Mobility Future with zero Emission Fuels from Renewable Electricity; Kraftstoffstudie II Final Report; Springer: Berlin/Heidelberg, Germany, 2016. [CrossRef]

115. Agora Verkehrswende; Agora Energiewende; Frontier Economics. The Future Cost of Electricity-Based Synthetic Fuels. 2018. Available online: https:/ / static.agora-verkehrswende.de/fileadmin/Projekte/2017/Die_Kosten_synthetischer_Brenn-_und_ Kraftstoffe_bis_2050/Agora_SynKost_Study_EN_WEB.pdf (accessed on 2 May 2018).

116. Dena. Dena-Leitstudie Integrierte Energiewende (dena Lead Study on Integrated Energy Transition) Impulse für die Gestaltung des Energiesystems bis 2050. 2018. Available online: https://www.dena.de/fileadmin/dena/Dokumente/Pdf/9261_denaLeitstudie_Integrierte_Energiewende_lang.pdf (accessed on 15 December 2020).

117. Kost, C.; Schlegl, T. Stromgestehungskosten erneuerbare Energien (Electricity Generation Costs Renewable Energies). 2018. Available online: https://www.ise.fraunhofer.de/content/dam/ise/de/documents/publications/studies/DE2018_ISE_Studie_ Stromgestehungskosten_Erneuerbare_Energien.pdf (accessed on 15 December 2020). 
118. World Bank. State and Trends of Carbon Pricing 2020. 2020. Available online: https:/ /openknowledge.worldbank.org/bitstream/ handle/10986/33809/9781464815867.pdf?sequence=4\&isAllowed=y (accessed on 16 December 2020).

119. Manager Magazin. CO2-Steuern und Emissionshandel: Diese CO2-Preise Gibt es Schon Heute (CO2 Taxes and Emissions Trading: These CO2 Prices Already Exist Today). 2019. Available online: https:/ /www.manager-magazin.de/fotostrecke/co2-steuerdiese-preise-gibt-es-schon-heute-fotostrecke-169692.html (accessed on 30 November 2020).

120. The Regional Greenhouse Gas Initiative. Elements of RGGI. Available online: https:/ /www.rggi.org/program-overview-anddesign/elements (accessed on 30 November 2020).

121. C40. C40: Shenzhen Carbon Emission Trading System. Available online: https://www.c40.org/case_studies/shenzhen-carbonemission-trading-system (accessed on 30 November 2020).

122. Center for Climate and Energy Solutions. California Cap and Trade. Available online: https://www.c2es.org/content/californiacap-and-trade/ (accessed on 30 November 2020).

123. Åkerfeldt, S.; Waluszewski, D. Carbon Taxation in Sweden. 2020. Available online: https://www.government.se/492a0 1/contentassets / 419eb2cafa93423c891c09cb9914801b/200224-carbon-tax-sweden---general-info.pdf (accessed on 16 December 2020).

124. Quandl. ECX EUA Futures, Continuous Contract \#1 (C1) (Front Month). Available online: https://www.quandl.com/data/ CHRIS/ICE_C1-ECX-EUA-Futures-Continuous-Contract-1-C1-Front-Month (accessed on 16 December 2020).

125. World Bank. State and Trends of Carbon Pricing 2018. 2018. Available online: https:/ / openknowledge.worldbank.org/bitstream/ handle/10986/29687/9781464812927.pdf?sequence=5\&isAllowed=y (accessed on 16 December 2020).

126. California Environmental Protection Agency. Overview of ARB Emissions Trading Program. 2015. Available online: https://ww2 .arb.ca.gov/sites/default/files/classic/ / cc/capandtrade/guidance/cap_trade_overview.pdf (accessed on 16 December 2020).

127. European Energy Exchange AG. China Beijing Environment Exchange (CBEEX). Available online: https://www.eex.com/en/ markets/environmental-markets/chinese-carbon-market (accessed on 16 December 2020).

128. California Air Ressource Board. California and Québec Carbon Allowance Prices. 2020. Available online: https://ww2.arb.ca. gov/sites/default/files/2020-09/carbonallowanceprices_0.pdf (accessed on 16 December 2020).

129. Office Publications. Regulation (EC) No 595/2009 of the European Parliament and of the Council of 18 June 2009 on TypeApproval of Motor Vehicles and Engines with Respect to Emissions from Heavy Duty Vehicles (Euro VI) and on Access to Vehicle Repair and Maintenance Information and Amending Regulation (EC) No 715/2007 and Directive 2007/46/EC and Repealing Directives 80/1269/EEC, 2005/55/EC and 2005/78/EC. Regulation (EC) No 595/2009. 2019. Available online: https:/ / eur-lex.europa.eu/legal-content/DE/TXT/?uri=CELEX\%3A32009R0595 (accessed on 15 December 2020).

130. Office Publications. Regulation (EU) 2019/1242 of the European Parliament and of the Council of of 20 Junel 2019 Setting $\mathrm{CO}_{2}$ Emission Performance Standards for New Heavy-Duty Vehicles and Amending Regulations (EC) No 595/2009 and (EU) 2018/956 of the European Parliament and of the Council and Council Directive 96/53/EC; 2019. Available online: https:/ / eur-lex.europa.eu/legal-content/EN/LSU/?uri=CELEX\%3A32019R1242 (accessed on 15 December 2020).

131. Rexeis, M.; Quaritsch, M.; Hausberger, S.; Silberholz, G.; Kies, A.; Steven, H.; Goschütz, M.; Vermeulen, R. VECTO Tool Development: Completion of Methodology to Simulate Heavy Duty Vehicles' Fuel Consumption and CO2 Emissions. Upgrades to the Existing Version of VECTO and Completion of Certification Methodology to be Incorporated into a Commission Legislative Proposal. 2017. Available online: https:/ / ec.europa.eu/clima/sites/clima/files/transport/vehicles/docs/sr7_lot4_final_report_ en.pdf (accessed on 2 February 2021).

132. Statista. Mobility Market Outlook. Available online: https://www.statista.com/outlook/mobility-markets (accessed on 23 September 2020).

133. ADAC. Database for Vehicles. Available online: https://www.adac.de/rund-ums-fahrzeug/autokatalog/marken-modelle/ (accessed on 18 December 2020).

134. AutoScout24. Fahrzeugbewertung. Available online: https://www.autoscout24.de/fahrzeugbewertung/ (accessed on 15 July 2020).

135. KBA. Fahrzeugzulassungen (FZ): Neuzulassungen von Kraftfahrzeugen nach Umwelt-Merkmalen. Jahr 2019. Available online: https://www.kba.de/DE/Statistik/Produktkatalog/produkte/Fahrzeuge/fz14_n_uebersicht.html (accessed on 18 December 2020).

136. BMWi. Bekanntmachung der Richtlinie zur Förderung des Absatzes von elektrisch betriebenen Fahrzeugen (Umweltbonus). Available online: https://www.bmwi.de/Redaktion/DE/Downloads/B/bekanntmachung-der-richtlinie-zur-foerderung-absatzesvon-elektrisch-betriebenen-fahrzeugen-umweltbonus.pdf?_blob=publicationFile\&v=4 (accessed on 18 December 2020).

137. check24.de. Vehicle Insurance Comparison Site. Available online: https://www.check24.de/kfz-versicherung/ (accessed on 25 July 2020).

138. Bundesregierung. Entwurf eines Siebten Gesetzes zur Änderung des Kraftfahrzeugsteuergesetzes. Available online: https:// www.bundesfinanzministerium.de/Content/DE/Gesetzestexte/Gesetze_Gesetzesvorhaben/Abteilungen/Abteilung_III/19 _Legislaturperiode/2020-06-12-7-Aenderung-Kraftfahrzeugsteuergesetz/1-Regierungsentwurf.pdf?_blob=publicationFile\& $\mathrm{v}=2$ (accessed on 18 December 2020).

139. Bundesregierung. Kraftfahrzeugsteuergesetz in der Fassung der Bekanntmachung vom 26. September 2002 (BGBl. I S. 3818). Available online: http:/ / www.gesetze-im-internet.de/kraftstg/KraftStG_2002.pdf (accessed on 17 December 2020). 
140. TÜV. Hauptuntersuchung (HU) Gebühren. Available online: https://www.tuvsud.com/de-de/branchen/mobilitaet-undautomotive/hauptuntersuchung/gebuehren (accessed on 25 September 2020).

141. ADAC. Autokosten-Rechner. Available online: https://www.adac.de/infotestrat/autodatenbank/autokosten/autokostenrechner/default.aspx (accessed on 10 October 2020).

142. Reifendirekt.de. Reifendirekt. Available online: https://www.reifendirekt.de (accessed on 10 October 2020).

143. DAT. DAT Report 2018. 2018. Available online: https://www.dat.de/news/dat-report-2018-jetzt-erhaeltlich/ (accessed on 18 December 2020).

144. ADAC. ADAC Autokosten Herbst/Winter 2019/2020-Kostenübersicht für über 1.600 aktuelle Neuwagen-Modelle. Available online: https:/ /www.adac.de/_mmm/pdf/autokostenuebersicht_47085.pdf (accessed on 18 December 2020).

145. INRIX. INRIX Studie zu den Kosten des Autofahrens: Parken Verursacht die Höchsten laufenden Ausgaben. Available online: https:/ /inrix.com/press-releases /inrix-studie-zu-den-kosten-des-autofahrens-parken-verursacht-die-hochsten-laufendenausgaben/ (accessed on 11 August 2020).

146. Fahrrad.de. Fahrrad.de-Studie zu Allgemeinen Fahrradnutzung in Deutschland 2015. Available online: https://www.fahrrad.de/ on/demandware.static/- /Library-Sites-bikester/default/dw7f90cb9f/Blog/studie-fahrradnutzung-deutschland.pdf (accessed on 17 December 2020).

147. VSF. VSF-Fachhandelsmitglieder zur Entwicklung des Jahres 2018 (Verbund Service und Fahrrad). Available online: https: / /nationaler-radverkehrsplan.de/de/aktuell/nachrichten/durchschnittspreis-aller-verkauften-fahrraeder-lag (accessed on 15 September 2020).

148. Zweirad-Industrie-Verband. Zweirad-Industrie-Verband (ZIV)-Wirtschaftspressekonferenz am 11. März 2020 in Berlin: ZahlenDaten-Fakten zum Fahrradmarkt in Deutschland 2019. 2019. Available online: https://www.ziv-zweirad.de/fileadmin/ redakteure/Downloads/Marktdaten/PK-2020_11-03-2020_Praesentation.pdf (accessed on 18 December 2020).

149. Zweirad-Industrie-Verband e.V. (ZIV). Average Cost of Bicycles; Interview with Head of Marketing and Communications: Bad Soden am Taunus, Germany, 2020.

150. Fahrradblog.de. Fahrradblog-Fahrradinspektion-Wartung mit Checkliste. Available online: https://www.fahrradblog.de/ sicherheit/fahrradinspektion-wartung-mit-checkliste/\#Kosten_fuer_Fahrradinspektion (accessed on 3 October 2020).

151. Schwalbe. Verschleiss Reifen. Available online: https://www.schwalbe.com/de/verschleiss (accessed on 3 August 2020).

152. GHOST-BIKES. User Manual for Bicycles. Available online: https://www.ghost-bikes.com/fileadmin/user_upload/Downloads/ Bedienungsanleitung/GHOST_bike_user_manual_german.pdf (accessed on 3 October 2020).

153. Bundesregierung. Elektrokleinstfahrzeuge-Verordnung vom 6. Juni 2019 (BGBl. I S. 756). Available online: https:/ / www.gesetzeim-internet.de/ekfv / BJNR075610019.html (accessed on 18 December 2020).

154. Bundesregierung. Straßenverkehrs-Zulassungs-Ordnung vom 26. April 2012 (BGBl. I S. 679). Available online: https://www. gesetze-im-internet.de/stvzo_2012/BJNR067910012.html (accessed on 18 December 2020).

155. Severengiz, S.; Finke, S.; Schelte, N.; Wendt, N. Life cycle assessment on the mobility service E-Scooter sharing. In Proceedings of the 2020 IEEE European Technology and Engineering Management Summit (E-TEMS), Dortmund, Germany, 5-7 March 2020; pp. 1-6, ISBN 978-1-7281-0903-9.

156. Laa, B.; Leth, U. Survey of E-scooter users in Vienna: Who they are and how they ride. J. Transp. Geogr. 2020, 89, 102874. [CrossRef]

157. Schellong, D.; Sadek, P.; Schaetzberger, C.; Barrack, T. The Promise and Pitfalls of E-Scooter Sharing. Available online: https: / / image-src.bcg.com/Images / BCG-The-Promise-and-Pitfalls-of-E-Scooter\%20Sharing-May-2019_tcm81-220107.pdf (accessed on 18 December 2020).

158. CarSharing.de. CarSharing-Städteranking 2019: Karlsruhe ist weiterhin Spitzenreiter. Available online: https://carsharing de/presse/pressemitteilungen/carsharing-staedteranking-2019-karlsruhe-ist-weiterhin-spitzenreiter (accessed on 18 December 2020).

159. Münzel, K.; Boon, W.; Frenken, K.; Vaskelainen, T. Carsharing business models in Germany: Characteristics, success and future prospects. Inf. Syst. Bus. Manag. 2018, 16, 271-291. [CrossRef]

160. ShareNow. Preisüberblick. Available online: https://www.share-now.com/de/de/pricing/?cid=sn_ppc_de_all_none_ performance_google_prsitelink_none_none_none_none_none_none_none_none\&gclid=CjwKCAjww5r8BRB6EiwArcckC5RgZb6mzlaAPSRDluq_OWgddb2W8a7nEk2sJR142NgSBfmgb-d3hoCj0MQAvD_BwE (accessed on 10 October 2020).

161. STATTAUTO. Preise. Available online: https://www.stattauto-muenchen.de/standardtarif/ (accessed on 18 December 2020).

162. MVG. MVG Rad. Available online: https://www.mvg.de/services/mobile-services/mvg-rad.html?pk_campaign=03_Generic_ Standort\&pk_kwd=\%2Bleihräder\%20\%2Bmünchen\&pk_source=GoogleAds\&pk_medium=cpc (accessed on 18 December 2020).

163. Heineke, K.; Kloss, B.; Scurtu, D.; Weig, F. Micromobility's 15,000-Mile Checkup. Available online: https:/ / www.mckinsey.com/ industries/automotive-and-assembly/our-insights/micromobilitys-15000-mile-checkup (accessed on 18 December 2020).

164. Tier. Tier App. Available online: https:/ / mytier.app (accessed on 18 December 2020).

165. Zagorskas, J.; Burinskienè, M. Challenges Caused by Increased Use of E-Powered Personal Mobility Vehicles in European Cities. Sustainability 2019, 12, 273. [CrossRef]

166. Emmy. Emmy-Sharing: Preise. Available online: https:/ /emmy-sharing.de (accessed on 2 November 2020).

167. Ennen, D.; Heilker, T. Ride-Hailing Services in Germany: Potential Impacts on Public Transport, Motorized Traffic, and Social Welfare. Available online: https:/ /ideas.repec.org/p/mut/wpaper/29.html (accessed on 18 December 2020). 
168. Uber. Uber. Available online: https:/ / www.uber.com/de/en/ (accessed on 18 December 2020).

169. München, L. TaxitarifO 410-Verordnung der Landeshauptstadt München über Beförderungsentgelte und Beförderungsbedingungen für den Verkehr mit Taxen (Taxitarifordnung). Available online: https://www.muenchen.de/rathaus/Stadtrecht/vorschrift/ 410.pdf (accessed on 18 December 2020).

170. MVV. MVV-Pläne zum Download. Available online: https://www.mvv-muenchen.de/plaene-bahnhoefe/plaene/index.html (accessed on 31 October 2020).

171. MVV. Pressemitteilungen. Available online: https://www.mvv-muenchen.de/mvv-und-service/presse/index.html (accessed on 20 August 2020). 